\title{
CAMA
}

Centre for Applied Macroeconomic Analysis

\section{Distribution Capital and the Short- and Long-run Import Demand Elasticity}

\section{CAMA Working Paper 56/2013 February 2013}

Mario J. Crucini

Department of Economics, Vanderbilt University, US

NBER

Centre for Applied Macroeconomic Analysis (CAMA), ANU

\section{J. Scott Davis}

Research Department, Texas, US

\section{Abstract}

International business-cycle models assume that home and foreign goods are poor substitutes. International trade models assume they are close substitutes. This paper constructs a model where this discrepancy is due to frictions in distribution. Imports need to be combined with a local non-traded input, distribution capital, which is slow to adjust. As a result, imported and domestic goods appear as poor substitutes in the short run. In the long run this non-traded input can be reallocated, and quantities can shift following a change in relative prices. Thus the observed substitutability between home and foreign goods gets larger as time passes. 


\section{Keywords}

\section{JEL Classification}

F1, F14, F44

\section{Address for correspondence:}

(E) cama.admin@anu.edu.au

The Centre for Applied Macroeconomic Analysis in the Crawford School of Public Policy has been established to build strong links between professional macroeconomists. It provides a forum for quality macroeconomic research and discussion of policy issues between academia, government and the private sector.

The Crawford School of Public Policy is the Australian National University's public policy school, serving and influencing Australia, Asia and the Pacific through advanced policy research, graduate and executive education, and policy impact. 


\title{
DISTRIBUTION CAPITAL AND THE SHORT- AND LONG-RUN IMPORT DEMAND ELASTICITY
}

Mario J. Crucini

J. Scott Davis

\begin{abstract}
International business-cycle models assume that home and foreign goods are poor substitutes. International trade models assume they are close substitutes. This paper constructs a model where this discrepancy is due to frictions in distribution. Imports need to be combined with a local non-traded input, distribution capital, which is slow to adjust. As a result, imported and domestic goods appear as poor substitutes in the short run. In the long run this non-traded input can be reallocated, and quantities can shift following a change in relative prices. Thus the observed substitutability between home and foreign goods gets larger as time passes.
\end{abstract}

This paper was begun while Davis was a visiting researcher at the Bank of Estonia and while Crucini was a visiting Senior Fellow at the Globalization and Monetary Policy Institute, Federal Reserve Bank of Dallas. We would like to thank participants at the 2011 Midwest Macro Meetings and the 2012 meetings of the System Committee for International Economic Analysis at the Federal Reserve Bank of San Francisco, particularly our discussant Andrea Raffo. In addition we would like to thank George Alessandria, Aurelijus Dabušinskas, Mick Devereux, Jonathan Heathcote, Finn Kydland, Sylvain Leduc,Jian Wang Lenno Uusküla and Mark Wynne for many helpful comments and suggestions. The views in this paper are those of the authors and do not necessarily reflect the views of the Federal Reserve Bank of Dallas, the Federal Reserve System, or the National Bureau of Economic Research. Mario Crucini acknowledges the generous financial support of the National Science Foundation (SES \#1030164).

(C) 2013 by Mario J. Crucini and J. Scott Davis. All rights reserved. Short sections of text, not to exceed two paragraphs, may be quoted without explicit permission provided that full credit, including (c notice, is given to the source.

Mario J. Crucini, Department of Economics, Vanderbilt University, Box 1819 Station B, Nashville, TN 37235-1819 and NBER; mario.j.crucini@vanderbilt.edu

J. Scott Davis, Research Department, 2200 North Pearl Street, Dallas, TX 75201; Scott.Davis@dal.frb.org 
The elasticity of substitution between home and foreign goods, also called the Armington elasticity, is one of the most important parameters in dynamic equilibrium models of international trade and business cycles. The parameter determines how quantities adjust in response to a change in relative prices, and thus determines how quantities of imports and exports adjust after a shift in the real exchange rate. Trade models rely on this parameter to determine the effect of trade policy and tariff rates on trade flows and welfare. Macro models rely on this parameter to determine the business cycle effects of certain macro shocks and the business cycle properties of international macro models.

The problem, as highlighted in Ruhl (2005) is that the trade literature and the international macro literature don't agree on the value of this parameter. Macro models, which are concerned with short-run fluctuations, generally ascribe a low value to this parameter. In the workhorse international real business cycle model, Backus, Kehoe and Kydland (1994) assign a value of 1.5 to the Armington elasticity and discuss how the model fails to replicate the negative co-movement between the terms of trade and net exports for values of the elasticity that are too high (above 3). In the calibration of their model, Kose and Yi (2006) use this same value. Stockman and Tesar (1995) use a Cobb-Douglas specification, and thus an elasticity of 1 , to aggregate home and foreign goods. Heathcote and Perri (2002) estimate the Armington elasticity from an equation that links changes in the real exchange rate to changes in net exports and relative production. They estimate a vale of the Armington elasticity of around 0.9. Corsetti, Dedola and Luduc (2008) use a value of around 0.85. They arrive at this value by calibrating their model to match certain features of the data, most notably the second moments of international relative prices like the real exchange rate and the terms of trade. Enders, Müller and Scholl (2011) construct a model to specifically explain the path of the real exchange rate and the terms of trade following either a productivity or government spending shock. They find that the model calibrated with a high elasticity of substitution yields counterfactual results as to the response of the real exchange rate following a shock.

Similarly in estimations using data on relative prices and import shares, Blonigen, Liebman and Wilson (1999) use quarterly data and find an average elasticity of about 0.81. Hooper, Johnson and Marquez (1998) and Gallaway, McDaniel and Rivera (2003) use a regression framework that allows them to distinguish between short- and long-run elasticities. They find that import demand elasticities are typically much larger in the long run than they are in the short run.

On the trade side, in their survey of the literature on trade costs, Anderson and van Wincoop (2004) find that the import demand elasticity is generally found to lie between 5 and 10. Hillberry et al. (2001) find long run estimates of the elasticity between 4 and 8. Hummels (1999) backs the elasticity parameter out of an estimated gravity model after 
estimating the elasticity of trade costs with respect to distance and finds the elasticity is about 5. In a similar fashion, Obstfeld and Rogoff (2000) find that when the elasticity of substitution is equal to 6 , the observed home bias in trade can be reconciled with estimated international trade costs. Head and Reis (2001), Clausing (2001), and Romalis (2007) each estimate the elasticity using U.S.-Canadian trade data from before and after the passage of the Canada-U.S. Free Trade Agreement and find the elasticity is somewhere between 6 and 11. Eaton and Kortum (2002) estimate a parameter that can be thought of as an import demand elasticity and find a value of 8.

The discrepancy between short- and long-run estimates of the elasticity of substitution is closely related to the literature on the J-curve. As noted in Junz and Rhomberg (1973) and Magee (1973), after a change in international relative prices, like an exchange rate depreciation, quantities do not always adjust instantaneously. This is closely related to the famous Marshall-Lerner condition, which states that in order for a currency depreciation to lead to an improvement in the trade balance, the sum of the absolute values of the import demand elasticity and export demand elasticity must be greater than one. If the sum of the elasticities is smaller than one in the short run then the currency depreciation will actually lead to a worsening of the trade balance, but if the elasticities get larger with time, then the trade balance should improve in the long run following an exchange rate depreciation. ${ }^{1}$

Junz and Rhomberg (1973) list five types of lags that may explain why quantities do not respond quickly to a change in the exchange rate. These are a recognition lag, a decision lag, a delivery lag, a replacement lag, and a production lag. More generally, these can be grouped into four categories.

Quantities may respond slowly to a change in relative price because consumers may be slow to notice a change in relative prices or sellers who have some market power may intentionally keep final goods prices from fluctuating following a transitory change in relative prices. Drozd and Nosal (2012) construct a search model where sales require some marketing capital. In this search framework, consumers initially may not notice a change in the relative price of imported goods. In their model, marketing capital is acquired slowly but can be lost quickly. As such, sellers have an incentive to keep transitory price changes from passing through into final goods prices. This is consistent with the empirical literature detailing the low pass through of exchange rate changes into import prices (see e.g. Campa and Goldberg $(2005))$.

\footnotetext{
${ }^{1}$ See Bahmani-Oskooee and Bolhasani (2008) and Boyd, Caporale and Smith (2001) for empirical evidence of a J-curve effect and evidence that the Marshall-Lerner condition holds in the long run but may not hold in the short run. See also Rose (1991) for evidence that the Marshall-Lerner condition does not hold and that the trade balance is largely independent of movements in the real exchange rate in at least the first two years following a change in the exchange rate.
} 
Another reason for the slow adjustment of quantities lies on the production side. It takes time for new producers to enter the export market following a favorable shift in relative prices. For example, there may be a cost to entering the export market. Ruhl (2005) presents a model where this entry cost is responsible for the discrepancy between macro and trade estimates of the elasticity of substitution. Following a transitory change in relative prices, like a temporary TFP shock, the present value of entering the export market is relatively low since the price advantage over foreign producers is only transitory. Thus the present value of the gains from entering the export market do not exceed the one-time fixed cost of exporting. However, following a permanent shock like a change in tariff rates, the present value is larger and thus more domestic firms will start exporting.

The third reason for the slow adjustment is due to frictions in replacement and inventory management. Alessandria, Kaboski and Midrigan (2010) present a model where fixed transactions costs to importing make trade "lumpy" and importing firms use S-s style inventory management. In their framework, following an exchange rate appreciation that makes foreign goods cheaper, importers will not immediately start buying more imports, especially when inventory levels are already high.

The model developed in this paper highlights another reason why exports and imports may be slow to respond to a change in relative prices, and thus why it may seem as if the substitutability of home and foreign goods is low in the short run relative to the long run. Essentially, the local non-traded component is sluggish. If in response to a positive foreign shock, home agents try to rapidly increase their purchases of imports, they strain the supply of this local component and face a steeply increasing marginal cost curve. In the short run the increasing marginal cost of the non-traded component largely cancels out the fall in the price of the imported good. As a result, the final prices paid by consumers may barely change in the short run in response to a change in relative price of imports. As time passes, the supply of the non-traded component is able to adjust more easily and thus there is a greater response to the quantity of imports following a change in their relative price.

The manner in which we model the non-traded distribution sectors and the traded sectors of national economies shares similarities with Burstein, Neves and Rebelo (2003), Burstein, Eichenbaum and Rebelo (2005; 2007), Corsetti and Dedola (2005) and Corsetti, Dedola and Luduc (2008). These authors discuss how the observed import demand elasticity is different from the Armington elasticity of substitution when the cost of a local non-traded component makes up a large part of the cost of an imported good. ${ }^{2}$ However these models cannot explain the fact that observed elasticities are low in the short run but high in the long run, which

\footnotetext{
${ }^{2}$ Anderson and van Wincoop (2004) report that distribution costs are responsible for $55 \%$ of the final price of an imported good, Berger et al. (2012) argue that the distribution margin is between $50-70 \%$.
} 
is our focus. We accomplish this by modeling the local non-traded component of cost as a function of both capital and labor. Labor can be reallocated within the period, but capital used in the distribution sector is predetermined. This gives rise to a non-traded factor input into domestic and imported final goods that is inelastically supplied in the short run, but gradually adjusts across uses in response to international relative prices.

The rest of this paper is organized as follows. The model is presented in section 1 . In the version of the model without local non-traded inputs, the model collapses to the benchmark IRBC model in Backus, Kehoe and Kydland (1994). The benchmark calibration of the model is presented in section 2. Here we will pay particular attention to the calibration of the key parameters involved in the distribution sector, and how the value of these parameters can be inferred from micro-data on prices. The results from the different versions of the model are presented in section 3. First we solve analytically for the observed import demand elasticity following a change in the relative price of imports. We then compare the different versions of the model, the version with a high elasticity of substitution as measured in the international trade literature, the version with the low elasticity as measured in the international macro literature, and the version with the high elasticity of substitution but a local non-traded component that is inelastically supplied in the short run. Only the version of the model with a high elasticity of substitution but an inelastically supplied local non-traded component can replicate both the short-run properties of aggregate prices and quantities that we observe in the data while also reproducing the observed long-run import demand elasticity. Finally, section 4 concludes with some directions for further research.

\section{The Model}

\subsection{Production}

There are two countries, home and foreign. Foreign variables are written with an asterisk $(*)$ and home variables are not. In the following description of the model, foreign equations are omitted for brevity.

An aggregate good is used by households for consumption, $C_{t}$, investment in production capital, $I_{t}$, and investment in distribution capital, $I_{d, t}$. This aggregate good, $y_{t}$, is formed through the combination of domestic and imported retail goods, which are combined in an Armington (1969) aggregator function with an elasticity of substitution $\rho$.

$$
C_{t}+I_{t}+I_{d, t}=y_{t}=\left[(\omega)^{\frac{1}{\rho}}\left(\tilde{y}_{D, t}\right)^{\frac{\rho-1}{\rho}}+(1-\omega)^{\frac{1}{\rho}}\left(\tilde{y}_{M, t}\right)^{\frac{\rho-1}{\rho}}\right]^{\frac{\rho}{\rho-1}} .
$$


where $\tilde{y}_{D, t}$ is the retail quantity of domestically produced goods and $\tilde{y}_{M, t}$ is the retail quantity of imported goods.

The demand for domestically produced or imported final goods as a function of aggregate expenditure is:

$$
\begin{aligned}
& \tilde{y}_{D, t}=\omega\left(\tilde{p}_{D, t}\right)^{-\rho} y_{t} \\
& \tilde{y}_{M, t}=(1-\omega)\left(\tilde{p}_{M, t}\right)^{-\rho} y_{t}
\end{aligned}
$$

where $\tilde{p}_{D, t}\left(\tilde{p}_{M, t}\right)$ is the retail price of domestic (imported) goods relative to the price of the home consumption good.

Substituting these demand functions into the aggregator function in (1) yields:

$$
\left[\omega\left(\tilde{p}_{D, t}\right)^{1-\rho}+(1-\omega)\left(\tilde{p}_{M, t}\right)^{1-\rho}\right]^{\frac{1}{1-\rho}}=1
$$

The retail quantity of the domestic good, $\tilde{y}_{D, t}$, is formed from the combination of a quantity of the domestic good, $y_{D, t}$, and good specific distribution services $d_{D, t}$.

$$
\tilde{y}_{D, t}=\left[\left(y_{D, t}\right)^{\frac{\gamma-1}{\gamma}}+\kappa^{\frac{1}{\gamma}}\left(d_{D, t}\right)^{\frac{\gamma-1}{\gamma}}\right]^{\frac{\gamma}{\gamma-1}}
$$

where $\kappa$ is the weight on distribution services, and $\gamma$ is the elasticity of substitution between tangible goods and distribution. This same production technology is used to define $\tilde{y}_{M, t}$ :

$$
\tilde{y}_{M, t}=\left[\left(y_{M, t}\right)^{\frac{\gamma-1}{\gamma}}+\kappa^{\frac{1}{\gamma}}\left(d_{M, t}\right)^{\frac{\gamma-1}{\gamma}}\right]^{\frac{\gamma}{\gamma-1}}
$$

where $y_{M, t}$ is the quantity of imported goods, and $d_{M, t}$ are distribution services employed in the distribution of these imports. In the functions for $\tilde{y}_{D, t}$ and $\tilde{y}_{M, t}$, when $\kappa=0$, the technology for domestic goods condenses to $\tilde{y}_{D, t}=y_{D, t}$ and $\tilde{y}_{M, t}=y_{M, t}$, and the model collapses to Backus et al. (1994). From this production function, the retail prices of domestic and imported goods relative to the home aggregate price deflator are:

$$
\begin{aligned}
& \tilde{p}_{D, t}=\left[\left(p_{D, t}\right)^{1-\gamma}+\kappa\left(c_{D, t}\right)^{1-\gamma}\right]^{\frac{1}{1-\gamma}} \\
& \tilde{p}_{M, t}=\left[\left(p_{M, t}\right)^{1-\gamma}+\kappa\left(c_{M, t}\right)^{1-\gamma}\right]^{\frac{1}{1-\gamma}}
\end{aligned}
$$

where $p_{D, t}\left(p_{M, t}\right)$ is the wholesale price of the domestic (imported) good, and $c_{D, t}\left(c_{M, t}\right)$ is the cost of domestic (import) distribution services.

Wholesale goods are produced by firms engaged in perfect competition, and thus the price of a home produced good is equal to its marginal cost of production, $M C_{t}$, and the 
price of a foreign produced good is equal to its marginal cost of production, $M C_{t}^{*}$. The relative price of the domestic good in the home market is thus $p_{D, t}=M C_{t}$ while the relative price in the home market of the imported good is $p_{M, t}=\frac{M C_{t}^{*}}{Q_{t}}$, where $Q_{t}$ is the real exchange rate defined as the foreign price level divided by the home price level.

Wholesale goods used domestically or exported to the foreign country, $y_{D, t}$ and $y_{M, t}^{*}$, exhaust current period production:

$$
y_{D, t}+y_{M, t}^{*}=A_{t} N_{t}^{1-\alpha} K_{t}^{\alpha}
$$

where $N_{t}$ and $K_{t}$ are labor and capital employed in the production of home country goods, and $A_{t}$ is a country specific total factor productivity parameter.

From this production function, the demand for labor and capital are given by $N_{t}=$ $(1-\alpha) \frac{M C_{t}}{w_{t}}\left(y_{D, t}+y_{M, t}^{*}\right)$ and $K_{t}=\alpha \frac{M C_{t}}{r_{t}}\left(y_{D, t}+y_{M, t}^{*}\right)$ where $w_{t}$ is the home real wage rate (in terms of the home consumption good), $r_{t}$ is the rental rate of physical capital employed in the production of home goods, and $M C_{t}=\frac{1}{A_{t}}\left(\frac{w t}{1-\alpha}\right)^{1-\alpha}\left(\frac{r_{t}}{\alpha}\right)^{\alpha}$.

Domestic distribution services employed in the final sales of domestic and imported goods, $d_{D, t}$ and $d_{M, t}$, are given by:

$$
\begin{aligned}
& d_{D, t}=A_{t}\left[\left(1-\hat{\alpha}_{d}\right)^{\frac{1}{\eta}}\left(N_{d D, t}\right)^{\frac{\eta-1}{\eta}}+\left(\hat{\alpha}_{d}\right)^{\frac{1}{\eta}}\left(K_{d D, t}\right)^{\frac{\eta-1}{\eta}}\right]^{\frac{\eta}{\eta-1}} \\
& d_{M, t}=A_{t}\left[\left(1-\hat{\alpha}_{d}\right)^{\frac{1}{\eta}}\left(N_{d M, t}\right)^{\frac{\eta-1}{\eta}}+\left(\hat{\alpha}_{d}\right)^{\frac{1}{\eta}}\left(K_{d M, t}\right)^{\frac{\eta-1}{\eta}}\right]^{\frac{\eta}{\eta-1}}
\end{aligned}
$$

where $N_{d D, t}$ and $K_{d D, t}$ are the labor and capital employed in the distribution of domestic goods, and $N_{d M, t}$ and $K_{d M, t}$ are the labor and capital employed in the distribution of imported goods. ${ }^{3}$

From the production functions for domestic and imported distribution services, the marginal costs of distribution are given by:

$$
\begin{aligned}
c_{D, t} & =\frac{1}{A_{t}}\left[\left(1-\hat{\alpha}_{d}\right)\left(w_{t}\right)^{1-\eta}+\hat{\alpha}_{d}\left(r_{D, t}\right)^{1-\eta}\right]^{\frac{1}{1-\eta}} \\
c_{M, t} & =\frac{1}{A_{t}}\left[\left(1-\hat{\alpha}_{d}\right)\left(w_{t}\right)^{1-\eta}+\hat{\alpha}_{d}\left(r_{M, t}\right)^{1-\eta}\right]^{\frac{1}{1-\eta}}
\end{aligned}
$$

where $r_{D, t}$ is the rental rate of capital used for domestic distribution services, $r_{M, t}$ is the rental

\footnotetext{
${ }^{3} \hat{\alpha}_{d}$ is the weight on capital in the production function, if the elasticity of substitution, $\eta=1$, $\hat{\alpha}_{d}$ would also be the share of distribution costs devoted to capital. When $\eta \neq 1$, the capital share is instead a function of the steady state wage and rental rate, $\alpha_{d}=\frac{\hat{\alpha}_{d}(r)^{1-\eta}}{\hat{\alpha}_{d}(r)^{1-\eta}+\left(1-\hat{\alpha}_{d}\right)(w)^{1-\eta}}$. In section 2 where we calibrate this parameter, to gain intuition we will calibrate capital's share of distribution costs, $\alpha_{d}$, but for a given steady state wage and rental rate, there is a one-to-one relationship between the capital share, $\alpha_{d}$, and the parameter $\hat{\alpha}_{d}$.
} 
rate for capital used in import distribution. The demand functions for capital and labor in the distribution of both domestic and imported goods are given by $K_{d D, t}=\left(1-\hat{\alpha}_{d}\right)\left(\frac{r_{D, t}}{c_{D, t}}\right)^{-\eta} \frac{d_{D, t}}{A_{t}^{1-\eta}}$, $K_{d M, t}=\left(1-\hat{\alpha}_{d}\right)\left(\frac{r_{M, t}}{c_{M, t}}\right)^{-\eta} \frac{d_{M, t}}{A_{t}^{1-\eta}}, N_{d D, t}=\hat{\alpha}_{d}\left(\frac{w_{t}}{c_{D, t}}\right)^{-\eta} \frac{d_{D, t}}{A_{t}^{1-\eta}}, N_{d M, t}=\hat{\alpha}_{d}\left(\frac{w_{t}}{c_{M, t}}\right)^{-\eta} \frac{d_{M, t}}{A_{t}^{1-\eta}}$.

\subsection{Households}

The one representative household per country derives utility from consumption and leisure. The household in the home country maximizes expected lifetime utility given by:

$$
E_{0} \sum_{t=o}^{\infty} \beta_{t} \frac{1}{1-\sigma}\left[\left(1-h_{t}\right)^{\theta}\left(C_{t}\right)^{1-\theta}\right]^{1-\sigma}
$$

where $\sigma$ is the coefficient of relative risk aversion and $h_{t}=N_{t}+N_{d D, t}+N_{d M, t}$.

We assume that international asset markets are complete. We can model this by assuming households share one worldwide budget constraint:

$$
\begin{aligned}
& C_{t}+I_{t}+I_{d, t}+q_{t}\left(C_{t}^{*}+I_{t}^{*}+I_{d, t}^{*}\right) \\
= & w_{t} h_{t}+r_{t} K_{t}+r_{D, t} K_{d D, t}+r_{M, t} K_{d M, t}+q_{t}\left(w_{t}^{*} h_{t}^{*}+r_{t}^{*} K_{t}^{*}+r_{D, t}^{*} K_{d D, t}^{*}+r_{M, t}^{*} K_{d M, t}^{*}\right) .
\end{aligned}
$$

\subsection{Capital Stocks}

There are three separate types of capital in each country, capital used in production, $K_{t}$, and capital used in distribution of either domestic or imported goods, $K_{d D, t}$ and $K_{d M, t}$. Capital employed in the production of goods evolves according to the usual capital accumulation equation:

$$
K_{t+1}=(1-\delta) K_{t}+I_{t}
$$

Distribution capital is earmarked for domestic or imported distribution services. The two markets are segmented in the sense that capital cannot be reallocated between domestic and imported retail distribution, both capital stocks are also subject to adjustment costs.. The two types of distribution capital each evolve according to their own capital accumulation equation:

$$
\begin{aligned}
& K_{d D, t+1}=(1-\delta) K_{d D, t}+\phi\left(\frac{I_{d D, t}}{K_{d D, t}}\right) K_{d D, t} \\
& K_{d M, t+1}=(1-\delta) K_{d M, t}+\phi\left(\frac{I_{d M, t}}{K_{d M, t}}\right) K_{d M, t}
\end{aligned}
$$

where the total investment in distribution capital, $I_{d, t}$, is allocated to investment in domestic 
or imported goods distribution, $I_{d, t}=I_{d D, t}+I_{d M, t}$.

The adjustment costs for distribution capital, $K_{d D, t}$ and $K_{d M, t}$ are described by the concave function $\phi(\cdot)\left(\phi^{\prime}>0\right.$ and $\left.\phi^{\prime \prime}<0\right)$. The stock of domestic or imported distribution capital is a state variable and cannot be changed in the current period. If there were no adjustment cost $\left(\phi^{\prime \prime}=0\right)$ then reallocation could be completed in one period. However when there are costs to adjusting the stocks of distribution capital, the optimal reallocation path may take multiple periods.

\section{Calibration}

The model described in the previous section is solved with a linear approximation and simulated in order to produce moments and impulse responses of key variables.

In the next section, simulations of the model under different values of the Armington elasticity, $\rho$, and the parameter controlling the distribution share, $\kappa$, are used to examine the importance of the distribution sector in affecting the substitutability of home and foreign traded goods. The rest of the model's parameters and their benchmark values are found in table 1.

The first six parameters: $\theta$, the exponent on leisure in the Cobb-Douglas utility function, $\sigma$, the coefficient of relative risk aversion, $\alpha$, the capital share, $\beta$, the discount factor, $\omega$, the weight on domestic goods in the Armington aggregator function, and $\delta$, the capital depreciation rate, are all taken from Backus, Kehoe and Kydland (1994) and found throughout the international real business cycle literature.

The next four parameters, $\gamma, \alpha_{d}, \eta$, and $\chi$ are the key parameters in distribution. ${ }^{4}$ To identify these parameters, we will calculate certain second moments of wholesale prices and distribution margins from the data and then calibrate the value of these four parameters so that the model can match specific moments of the data.

We use a panel data set of retail prices for over 300 goods in 123 cities where the price of each good in each city is observed annually from 1990-2005. The data-set is described in Crucini and Landry (2012). The dataset covers over 300 goods, but we exclude the goods that are very close to the definition of a non-traded good (like domestic cleaning help), and aggregate the remaining goods into four sectors, grocery items, non-food consumer goods, clothing, and transportation. The full list of goods in the dataset and how they are grouped into four categories is presented in the appendix. We restrict our attention to 13 U.S. cities,

\footnotetext{
${ }^{4} \chi$ describes the capital adjustment cost for capital used in distribution. Specifically $\chi=$ $\frac{\phi^{\prime \prime}\left(\frac{I_{d D, t}}{K_{d D, t}}\right)}{\phi^{\prime}\left(\frac{I_{d D, t}}{K_{d D, t}}\right)} \frac{I_{d D, t}}{K_{d D, t}}=\frac{\phi^{\prime \prime}\left(\frac{I_{d M, t}}{K_{d M, t}}\right)}{\phi^{\prime}\left(\frac{I_{d M, t}}{K_{d M, t}}\right)} \frac{I_{d M, t}}{K_{d M, t}}$.
} 
the list of these 13 cities is also presented in the appendix.

Before we discuss how the data is used, consider the price indices for the retail price and the marginal cost of distribution in (3) and (6). If we linearize these price indices, then the fluctuations in the final good price, $\tilde{p}_{i t}$, can be expressed as a combination of the fluctuations in the wholesale price, $\hat{p}_{i t}$, the wage rate (non-sector specific input into distribution), $\hat{w}_{t}$, and the rental rate for sector specific distribution capital, $\hat{r}_{i t}$ :

$$
\tilde{p}_{i t}=(1-s) \hat{p}_{i t}+s\left(1-\alpha_{d}\right) \hat{w}_{t}+s \alpha_{d} \hat{r}_{i t}
$$

where $s$ measures the steady state distribution margin, $s=\kappa\left(\frac{c_{D}}{\tilde{p}_{D}}\right)^{1-\gamma}=\kappa\left(\frac{c_{M}}{\tilde{p}_{M}}\right)^{1-\gamma}$.

In the data set we observe $\tilde{P}_{i j t}$, the retail price of the good from sector $i$ in city $j$ at time $t$. Crucini and Landry (2012) also provide data on the distribution margin for each good in the dataset, $s_{i}{ }^{5}$ Given these prices and the distribution margins we can estimate the following regression:

$$
\tilde{p}_{i j t}=\left(1-s_{i}\right) \mu_{i t}+s_{i} \mu_{j t}+s_{i} \mu_{i j t}
$$

where $\mu_{i t}$ is sector specific fixed effect intended to capture variation in wholesale prices $\left(\hat{p}_{i t}\right)$, and $\mu_{j t}$ is a city-fixed effect intended to capture variation in the city, but not good specific component of distribution $\left(\hat{w}_{t}\right)$. Furthermore we can calculate the total distribution cost, $\hat{c}_{i t}=\frac{\tilde{p}_{i j t}-\left(1-\kappa_{i}\right) \mu_{i t}}{\kappa_{i}}$.

With time series of $\hat{w}_{t}, \hat{p}_{i t}, \hat{c}_{i t}$ we can calculate the variance, the persistence, and the comovement of each one of the components of the retail price. These statistics are presented in table 2 . In this table, these statistics are computed using a few different detrending methods. The price data, $\tilde{p}_{i j t}$, is nominal, so the first step is to remove the nominal trend. In columns $1-3$, the nominal trend is removed by including a time dummy in the regression in equation (11). In columns 4-6, the nominal trend is removed by dividing all prices by the consumer price index, and in columns 7-9, there is no nominal detrending. Comparing each set of three columns shows that nominal detrending really doesn't have much of an effect on these statistics. This is due to the fact that the data is taken from 13 U.S. cities over the period 1990-2005, a period when inflation was low and stable.

But even after taking out a nominal trend, over this period there have been shifts in relative productivity between sectors, which would lead to non-stationary relative price changes that we would want to filter out before using the data to calibrate a stationary model (e.g. productivity improvements in the technology sector have led to a non-stationary fall in the relative price of computers over this period). To account for these non-stationary shifts in sectoral prices, we can either filter the sectoral price data, $\tilde{p}_{i j t}$, using an HP filter (with

\footnotetext{
${ }^{5}$ The distribution margins, $s$, are good specific, but is common across all locations and time.
} 
smoothing parameter 100 for annual data) or taking first-differences. Thus within each set of three columns in table 2, the first column filters each sectoral price with an HP filter, the second uses first-differences, and the third does nothing.

The first thing to notice is that the wholesale goods price, $\hat{p}_{i t}$, is extremely volatile when no filter is used. This is due to non-stationary shifts in relative prices across sectors. Once we use a filter to remove these non-stationary shifts in relative prices, the results in the table are largely invariant to which filter we use. The only noticeable difference is that the first-order autocorrelation coefficient is much lower using the first-differenced data, but all other statistics are largely the same. Thus in the following calibration exercise, we simply use the first column, the data using the time dummy for nominal detrending and the HP filter for additional detrending, as the benchmark set of statistics.

Simulated method of moments are employed to find the combination of $\gamma, \alpha_{d}, \eta$ and $\chi$ that minimizes the squared distance between the moments presented in the first column of table 2 and the corresponding moments from simulations of the model. These estimated parameters are listed in the bottom four rows of table 1.

The the optimal combination of $\gamma, \alpha_{d}, \eta$ and $\chi$ is chosen by varying all four parameters simultaneously, but to gain some intuition about the separate role of each of these four parameters related to the distribution sector, in tables 3 and 4 we vary one of these four parameters, while holding the other three constant.

The effect of varying the elasticity of substitution between tangible goods and distribution services, $\gamma$, is shown in columns 2-6 of table 3. The simulated method of moments exercise finds that the optimal value of $\gamma$ is 0.02 , implying that tangible goods and distribution services are nearly perfect compliments. The table reports the effect of increasing $\gamma$ while holding all other parameters constant. As $\gamma$ increases, there is very little change in either the volatility or the persistence of the wage rate, $\hat{w}_{t}$. However, the relative volatility of both the wholesale price and distribution costs falls as $\gamma$ increases. In the data, both wholesale prices, $\hat{p}_{i}$, and distribution costs, $\hat{c}_{i}$, are about two-thirds as volatile as the wage rate. When wholesale goods and distribution services are nearly perfect compliments, the model is able to replicate these relative volatilities. As $\gamma$ increases and the two become more substitutable, these relative volatilities fall, when $\gamma=0.8$, the price of wholesale goods and the cost of distribution are both about a third as volatile as the wage rate. Hence, $\gamma$ must be small, implying that wholesale goods and distribution services are compliments, to replicate the volatility of prices that we see in the data. Our estimates of a near perfect complementarity between wholesale goods and distribution services largely validate the calibration by Burstein, Neves and Rebelo (2003) and Burstein, Eichenbaum and Rebelo (2007).

In columns $7-11$ of the same table we vary $\alpha_{d}$, the labor share in the production of 
distribution services from 0.16 to 0.56 . Again we see that varying $\alpha_{d}$ has little effect on the volatility or persistence of the wage rate. Allowing the labor share to increase does have some effect on the relative volatilities of the wholesale price and the distribution costs, but the major effect of increasing $\alpha_{d}$ is in the co-movement between the wage rate and wholesale prices or between the wage rate and distribution costs. In the data, the correlation between the wage rate and the cost of distribution is about 0.34 . When $\alpha_{d}$ is small, and thus there is very little labor used in distribution, the model predicts that the co-movement between the two should be almost 0 . As $\alpha_{d}$ increases and thus there is more labor used in distribution, the correlation between the two will increases. However, as $\alpha_{d}$ gets too big, the correlation between the two gets too large, so to replicated the positive but modest correlation between the wage rate and the cost of distribution, $\alpha_{d}$ should be about 0.36 .

Similarly, in the data, the correlation between the wage rate and wholesale prices is about -0.27 . In the model, when $\alpha_{d}$ is small, the two are nearly uncorrelated, but as $\alpha_{d}$ increases, this correlation falls, but again, to replicate the negative, but modest, correlation, $\alpha_{d}$ should be about 0.36 .

In columns 2-6 of table 4 we vary $\eta$, the elasticity of substitution between capital and labor in the production of distribution services. Again we see that allowing $\eta$ to vary has little effect on the volatility or the persistence of the wage rate. However, as $\eta$ increases capital and labor in distribution become more substitutable, and the relative volatilities of both the distribution cost and the wholesale price falls. When $\eta$ is small, and capital and labor in distribution are nearly perfect compliments, both distribution costs and the wholesale prices should be about as volatile as the wage rate. When $\eta$ is higher and capital and labor are closer substitutes, these two prices are about half as volatile as the wage rate, in order to match the relative volatilities that we observe in the data, $\eta$ should be about 0.4 .

Finally, columns 7-11 of table 4 present the results from simulation of the model where $\chi$, the distribution capital adjustment cost parameter varies. Again, allowing $\chi$ to vary has little effect on the volatility or the persistence of the wage rate. Note that in contrast to the other three cases in tables 3 and 4, only when we vary $\chi$ do we see any significant effect on persistence. In the data, both the distribution cost and the wholesale price have a first-order autocorrelation coefficient of about 0.82 . When $\chi=0$, implying that there are no costs to adjusting the stocks of distribution capital, the persistence of these two variables is counterfactually low. Similarly, when $\chi$ is low, the relative volatilities of the two prices is too low, the correlation between the wage rate and the cost of distribution is too low, and the correlation between the wage rate and wholesale prices is too high. In order to replicate the moments we observe in the data, the model needs a modest investment adjustment cost parameter of 0.18 . 


\subsection{Shock Process}

In this real business cycle model, fluctuations in total factor productivity drive business cycle fluctuations. The $A_{t}$ and $A_{t}^{*}$ variables in (4) are exogenous country specific shocks. Using data on gross value added, total employment, and gross fixed capital formation from the OECD's STAN database, we estimate two series of total factor productivity for the United States and the combination of Germany, France, Italy, the Netherlands, Belgium, Austria, and Finland from 1977-2007. The data is available at annual frequency, we first estimate a $\operatorname{VAR}(1)$ with the two series using the annual data, and then we impose symmetry and convert this annual process to a quarterly process. The resulting quarterly shock process for the model is:

$$
\left[\begin{array}{l}
A_{t+1} \\
A_{t+1}^{*}
\end{array}\right]=\left[\begin{array}{cc}
0.83 & 0 \\
0 & .083
\end{array}\right]\left[\begin{array}{l}
A_{t} \\
A_{t}^{*}
\end{array}\right]+\left[\begin{array}{l}
\varepsilon_{t} \\
\varepsilon_{t}^{*}
\end{array}\right]
$$

where $\operatorname{var}\left(\varepsilon_{t}\right)=\operatorname{var}\left(\varepsilon_{t}^{*}\right)=0.12$ and $\operatorname{corr}\left(\varepsilon_{t}, \varepsilon_{t}^{*}\right)=0.31$.

This shock process assumes that TFP is the same across both the production sector and the distribution sector within a country, as in the production functions in (4) and (5). Alternatively we can assume that there is a separate TFP process for the distribution sector, and thus the $A_{t}$ in (5) is replaced with $A_{t}^{d}$. There are now four TFP processes to estimate, so with the STAN data, instead of considering total value added, total employment, and total capital formation in order to find aggregate TFP, we can consider these same series separated into industry and service sectors. Thus using both industrial and service sector TFP for both the U.S. and Europe, we can estimate a $\operatorname{VAR}(1)$ with the four TFP variables, $A_{t}, A_{t}^{*}, A_{t}^{d}$, and $A_{t}^{d *}$. Again, this data is available at an annual frequency, so after estimating the annual process, imposing symmetry across countries, and converting to a quarterly process, the resulting shock process for the model is:

$$
\mathbf{A}_{t+1}=\rho \mathbf{A}_{t}+\varepsilon_{t}
$$

where $\mathbf{A}_{t}=\left[\begin{array}{llll}A_{t} & A_{t}^{*} & A_{t}^{d} & A_{t}^{d *}\end{array}\right]^{\prime}$ and $E\left(\varepsilon_{t} \varepsilon_{t}^{\prime}\right)=\Omega$, where 


$$
\boldsymbol{\rho}=\underset{\left.\begin{array}{rrrr}
0.78 & 0.06 & 0.07 & -0.19 \\
0.06 & 0.78 & -0.19 & 0.07 \\
0.00 & 0.02 & 0.84 & -0.07 \\
0.02 & 0.00 & -0.07 & 0.84
\end{array}\right]}{\boldsymbol{\Omega}=\mathbf{1 0}^{-1} \times\left[\begin{array}{rrrr}
6.92 & 0.63 & 0.32 & 0.77 \\
0.63 & 6.92 & 0.77 & 0.32 \\
0.32 & 0.33 & 0.97 & 0.47 \\
0.33 & 0.32 & 0.47 & 0.97
\end{array}\right]}
$$

\section{Results}

\subsection{Distribution costs and the observed elasticity of substitution}

The elasticity of substitution between home and foreign goods is defined as the percentage change in relative quantities divided by the percentage change in relative prices:

$$
\varepsilon_{t}=\frac{d \ln \left(\frac{y_{M, t}}{y_{D, t}}\right)}{d \ln \left(\frac{p_{D, t}}{p_{M, t}}\right)}
$$

To find this elasticity in terms of the model's structural parameters, consider the demand functions in (2) and find an expression for $\ln \left(\frac{\tilde{y}_{M, t}}{\tilde{y}_{D, t}}\right):^{6}$

$$
\ln \left(\frac{\tilde{y}_{M, t}}{\tilde{y}_{D, t}}\right)=\ln \left(\frac{1-\omega}{\omega}\right)-\rho \ln \left(\frac{\tilde{p}_{M, t}}{\tilde{p}_{D, t}}\right)
$$

If $\tilde{p}_{D, t}=p_{D, t}$ and $\tilde{p}_{M, t}=p_{M, t}$, then the elasticity, $\varepsilon_{t}$ equals the structural parameter $\rho$. If however, the price of imports relative to domestic goods at the wholesale level varies over time relative to that at the retail level, then the elasticity $\varepsilon_{t}$ becomes a function of other parameters in the model, and generally time varying.

To see this, expand the elasticity expression in (12):

\footnotetext{
${ }^{6}$ The model is calibrated such that $\gamma$, the elasticity of substitution between intermediate goods and distribution services is equal to zero. In this derivation of the observed elasticity of substitution we are using that fact in order to simplify and say $d \ln \left(\frac{\tilde{y}_{M, t}}{\tilde{y}_{D, t}}\right)=d \ln \left(\frac{y_{M, t}}{y_{D, t}}\right)$. If instead $\gamma>0$, then the expression linking wholesale quantities and retail quantities will be more complicated, but the intuition is the same.
} 


$$
\varepsilon_{t}=\frac{d \ln \left(\frac{\tilde{y}_{M, t}}{\tilde{y}_{D, t}}\right)}{d \ln \left(\frac{\tilde{p}_{D, t}}{\tilde{p}_{M, t}}\right)} \frac{d \ln \left(\frac{\tilde{p}_{D, t}}{\tilde{p}_{M, t}}\right)}{d \ln \left(\frac{p_{D, t}}{p_{M, t}}\right)}=\rho \frac{d \ln \left(\frac{\tilde{p}_{D, t}}{\tilde{p}_{M, t}}\right)}{d \ln \left(\frac{p_{D, t}}{p_{M, t}}\right)}
$$

Thus the change in relative quantities following a change in wholesale prices is the Armington elasticity of substitution between home and foreign goods, $\rho$, multiplied by the elasticity of relative prices at the consumer level with respect to changes in relative prices at the wholesale level. ${ }^{7}$ Given the expressions for the final consumer prices in (3), this elasticity can be written as:

$$
\frac{d \ln \left(\frac{\tilde{p}_{D, t}}{\tilde{p}_{M, t}}\right)}{d \ln \left(\frac{p_{D, t}}{p_{M, t}}\right)} \approx \frac{(1-s) d \ln \left(\frac{p_{D, t}}{p_{M, t}}\right)+s d \ln \left(\frac{c_{D, t}}{c_{M, t}}\right)}{d \ln \left(\frac{p_{D, t}}{p_{M, t}}\right)}
$$

Thus the observed elasticity of substitution between domestic and imported goods following a change in wholesale prices is:

$$
\varepsilon_{t}=\rho\left((1-s)+s \frac{d \ln \left(\frac{c_{D, t}}{c_{M, t}}\right)}{d \ln \left(\frac{p_{D, t}}{p_{M, t}}\right)}\right)
$$

In response to a change in relative wholesale prices, the market will react by shifting resources from one type of distribution to another. Specifically, if domestic goods become relatively more expensive than imported goods at the wholesale level, $d \ln \left(\frac{p_{D, t}}{p_{M, t}}\right)>0$, then the quantity demanded of imported goods should increase and the quantity demanded of domestic goods should fall.

There are two inputs into the production of distribution services, non-sector specific labor and sector specific capital. From equation (6), fluctuations in the ratio of the two distribution margins, $d \ln \left(\frac{c_{D, t}}{c_{M, t}}\right)$, can be written as:

$$
d \ln \left(\frac{c_{D, t}}{c_{M, t}}\right)=\alpha_{d} d \ln \left(\frac{w_{t}}{w_{t}}\right)+\left(1-\alpha_{d}\right) d \ln \left(\frac{r_{D, t}}{r_{M, t}}\right)=\left(1-\alpha_{d}\right) d \ln \left(\frac{r_{D, t}}{r_{M, t}}\right)
$$

Thus the observed elasticity of substitution, $\varepsilon_{t}$, is:

$$
\varepsilon_{t}=\rho\left((1-s)+s\left(1-\alpha_{d}\right) \frac{d \ln \left(\frac{r_{D, t}}{r_{M, t}}\right)}{d \ln \left(\frac{p_{D, t}}{p_{M, t}}\right)}\right)
$$

Following the shift in the quantity demanded of imported and domestic wholesale goods,

\footnotetext{
${ }^{7}$ See Crucini and Yilmazkuday (2009) for empirical evidence using micro-level price data of how distribution costs lead to a long-run disconnect between producer and consumer prices.
} 
the demand for imported goods distribution services will increase and the demand for domestic goods distribution services will fall. Labor used in the production of distribution services can be reallocated within the period, but in the short run distribution capital cannot be reallocated. Thus following a change in relative wholesale prices that leads to an increased demand for imports and a decreased demand for domestic goods, there is an excess demand for imported goods distribution capital and an excess supply of domestic goods distribution capital. This implies that the equilibrium cost of domestic goods distribution capital should fall and the cost of imported goods distribution capital should rise. Thus the following inequality should hold in the short run: ${ }^{8}$

$$
\frac{d \ln \left(\frac{r_{D, t}}{r_{M, t}}\right)}{d \ln \left(\frac{p_{D, t}}{p_{M, t}}\right)}<0
$$

Given this excess demand in one market and the excess supply in another, agents will change their future investment plans. Investment in imported goods distribution capital will increase and investment in domestic good distribution capital will decrease.

If there are no adjustment costs in the capital accumulation equations in (10) then plans for investment in new domestic or import distribution capital are changed and the capital stocks reach their new efficient level in the next period. If there are capital adjustment costs then the adjustment may be slower and it may take multiple periods to clear out any excess demand or supply in the market for distribution services and reach a point where $r_{D, t}=r_{M, t}$.

Given this change in the relative distribution costs, in the short run $\varepsilon_{t}<(1-s) \rho$, and as time passes and capital is reallocated, $\varepsilon_{t}$ approaches $(1-s) \rho$.

If $\alpha_{d}=1$, non-sector specific labor is the only input into distribution. Given that labor may be reallocated across uses within the period, the cost of distribution services must be the same for both domestic goods and imports, $c_{D, t}=c_{M, t}$. In this case $\varepsilon_{t}=(1-s) \rho$ for all $t$.

The path of the observed elasticity of substitution following a productivity shock is presented in figure 1. The figure presents the path of the observed elasticity of substitution, as measured by (12) for 40 quarters following a shock in the three different cases. The first is where the Armington elasticity of substitution between home and foreign goods is equal to 4 and there is no distribution sector, in the second case the Armington elasticity is equal to 0.9 and there is no distribution sector, and in the third the Armington elasticity is equal to 8 but distribution costs make up approximately $50 \%$ of the final cost of a good, as in

\footnotetext{
${ }^{8}$ Empirically, Goldberg and Campa (2010) find that following a 1\% exchange rate depreciation that results in a $1 \%$ increase in the price of foreign currency denominated imports at the dock, the distribution costs of imports falls by $0.47 \%$.
} 
Corsetti and Dedola (2005). Given that $s=0.5$ and $\rho=8$, the observed long run elasticity of substitution is equal to 4 .

In the two cases where there is no distribution sector the observed elasticity of substitution is simply equal to the Armington elasticity. In the case where there is a distribution sector, the observed elasticity is initially close to zero since distribution capital is a state variable and cannot be instantaneously reallocated from the domestic goods sector to the imported goods sector, and the elasticity of substitution between capital and labor in the distribution sector is low, meaning that some labor is shifted into the high demand sector, but not much. Agents cannot reallocate existing capital but can change investment plans subject to investment adjustment costs, so over time capital in one sector is allowed to depreciate without replacement while the stock of distribution capital increases in the other. Thus over time as the stocks of distribution capital change, the observed substitutability between home and foreign goods increases.

\subsection{Impulse Responses}

The responses of home and foreign GDP and its components to a positive home TFP shock are presented in figures 2 and 3. Figure 2 presents the responses of home and foreign GDP and investment under three cases mentioned earlier, where the Armington elasticity, $\rho$, is equal to 4 and the distribution margin is equal to 0, where the Armington elasticity is equal to 0.9 and the distribution margin is equal to 0 , and where the Armington elasticity is equal to 8 but the distribution margin is set to $50 \%$. Figure 3 does the same for consumption and net exports.

For the case where the elasticity is equal to 4 but there are no distribution costs, the figures show the familiar result that in an international real business cycle model with complete international asset markets and a high degree of substitutability between home and foreign goods. Following a productivity shock in the home country, there is a sharp increase in home investment demand. The foreign country does not have the same increase in investment demand and any increase in foreign investment is tempered in order to ship goods to fuel the productivity induced investment boom in the home country. Thus in the immediate aftermath of the shock, before the benefits of the shock in terms of increased home production are felt, the home country runs a current account deficit and the foreign country runs a current account surplus.

Within a few quarters there is a reversal in the current account as the higher production leads to increased saving in the home country, some of this increased savings is shipped abroad in the form of high home current account surpluses. Thus after the first few quarters, 
the home country runs a large and persistent current account surplus and the foreign country runs a large and persistent deficit.

The current account dynamics change in significant ways when home and foreign goods are less substitutable. When the elasticity of substitution is equal to 0.9 , the foreign goods can't as easily be used to fuel a home country investment boom, so there is more of an increase in foreign investment in the aftermath of the shock. Furthermore, once the increased home productivity leads to an increase in home production and home saving, foreign agents can't as easily consume the benefits of the productivity fueled boom in the home country and thus do not run large current account deficits when substitutability is low.

The responses from the model with distribution costs are very similar to the responses when the technological elasticity of substitution is equal to 0.9. The observed long-run elasticity of substitution between home and foreign goods may be equal to 4 , but in the short run, home and foreign goods are not highly substitutable. The figure shows that there is more of an increase in foreign investment in the immediate aftermath of the shock as foreign goods are not as easily diverted for use in the home country investment boom. And since without adequate distribution channels, foreign agents cannot as easily substitute the excess production from the home country for their own goods, foreign agents import less and thus run a smaller trade deficit.

Following a shock to productivity in one country, prices and quantities need to adjust to restore equilibrium. Figures 2 and 3 show that when there is low substitutability between home and foreign goods, there is not much response to net exports following a shock, so it must be that most of the burden of adjustment falls on international relative prices, namely the terms of trade and the real exchange rate. ${ }^{9}$

Figure 4 shows the responses of the home country terms of trade and the real exchange rate following a positive home TFP shock. When the technological elasticity of substitution is equal to 4 and there are no distribution costs there is little movement in either the terms of trade or net exports following a shock. When the elasticity of substitution is equal to 0.9 , there is much more movement in both the terms of trade and the real exchange rate. Similarly when the Armington elasticity of substitution is equal to 8 but there are distribution costs there is significant movement in both the terms of trade and the real exchange rate following the shock. Thus when there are distribution costs and a distribution sector that is slow to adjust, the economy with a high elasticity of substitution but distribution costs acts a lot like the economy with a low elasticity of substitution, following a shock, quantity variables

\footnotetext{
${ }^{9} \mathrm{~A}$ similar argument (but one that relied on incomplete pass-through to explain the low substitutability) is given in Devereux and Engel (2002) to explain the high volatility of exchange rates that we observe in the data.
} 
like like exports and imports cannot adjust quickly to restore equilibrium, so the burden of adjustment falls on prices like the terms of trade and the real exchange rate.

\subsection{Volatility and co-movement of certain macro variables}

The standard deviation and co-movement of GDP, the components of GDP, and international prices like the terms of trade and the real exchange rate are listed in table 5 . The first two columns of the table list these moments calculated from the data either for the U.S. or the Euro area. The data is quarterly from 1984 to 2007. The rest of the table presents these moments as calculated from simulations of the model. In the first three columns of data from simulations of the model (Model 1), exports and imports (and thus net exports and GDP) are measured with prices that are allowed to vary over the cycle. Exports and imports are measured with constant (steady-state) prices in the last three columns of the table (Model 2).

The simulations of the model are conducted under the three alternative parameterizations that were used in the impulse response analysis. The table shows that when the Armington elasticity of substitution is equal to 4 but there are no distribution costs the model predicts too little volatility in both consumption and international prices like the terms of trade or the real exchange rate. The model also predicts a low cross-country co-movement in production side variables like output and employment, and a high cross-country co-movement in consumption.

These features of the model where shown earlier in the impulse response analysis. Following a positive shock in one country, the country that experienced the positive shock can easily export their surplus production to the less productive country. This leads to too much consumption smoothing, and since quantities adjust so easily in order to clear markets internationally, there is not much movement in either the terms of trade or the real exchange rate. The high substitutability of home and foreign goods means that agents are very willing to have changes in the composition of their consumption and take advantage of productivity differentials across countries to maximize total consumption, and this results in a low cross-country correlation in production and a high cross-country correlation in consumption.

When the elasticity of substitution between home and foreign goods is 0.9 , the low substitutability between home and foreign goods means that the country that experiences a positive shock cannot as easily export their surplus production to the foreign country. This implies that net exports are less volatile and consumption is more volatile. Lower substitutability means that production responsibilities cannot as easily be "shared" between countries, so cross-country output co-movement is higher and cross country consumption 
co-movement is lower. Given that net exports are less volatile when home and foreign goods are not as easily substitutable, international prices like the real exchange rate and the terms of trade must move more to restore equilibrium following a shock.

The table shows that in the version of the model where the Armington elasticity of substitution between home and foreign goods is equal to 8 but there are distribution costs, the volatility and co-movement from simulations of the model are very close to the moments predicted from the model with the low Armington elasticity. Even though the Armington elasticity is high, since distribution channels cannot be adjusted quickly following a shock, at short horizons home and foreign goods are much less substitutable. As a result, net exports are not very volatile, and the model with distribution costs is able to predict the high volatility of the real exchange rate and the terms of trade even when the observed long run elasticity of substitution between home and foreign goods is equal to 4 . Since home and foreign goods cannot be easily substituted in the short run, there is less consumption smoothing, lower cross-country consumption correlation, and higher cross-country correlation in output and investment.

In the last three columns of the table exports and imports are measured with constant (steady state) prices. In this model, frictions in distribution may severely hamper the ability of export and import volumes to respond following a shock. Measuring exports and imports with constant prices allows us to study the behavior of trade quantities, and ensure that these results are not simply driven by changes in the terms of trade.

The table shows that measuring exports and imports with constant price has little effect on most variables in the model. None of the variances or co-movements involving GDP, net exports, exports, or imports are significantly affected. The volatility of exports and imports drops when measured with constant prices. In the model, the volatility of the volume of exports and imports is highest when goods are very substitutable. This volatility falls in the model where goods are less substitutable. When there are frictions in the distribution margin, the volatility of export and import volumes predictably lies between these two extremes. $^{10}$

\subsubsection{The S-curve}

As discussed in Backus, Kehoe and Kydland (1994), the contemporaneous correlation between international relative prices like the terms of trade or the real exchange rate and net

\footnotetext{
${ }^{10}$ It should be noted that the volatility of exports and imports in the model is very low compared to what we observe in the data. As discussed in Engel and Wang (2011), this feature of the data is due to the fact that much trade seems to be concentrated in the more volatile durable goods sector. Since this model does not provide a special role for durable goods trade over non-durable trade, export and import volumes should in the model should still be below what they are in the data.
} 
exports is low and maybe even negative. The last two rows of table 5, show that the correlation between the terms of trade and net exports or between the real exchange rate and net exports is negative in the United States. The same correlations are positive but close to zero in the Euro Area. Furthermore, the table shows that simulations of the model where the Armington elasticity is equal to 4 but there are no distribution costs predict a high contemporaneous correlation between relative prices and net exports, that is the model predicts that when there is a depreciation in the real exchange rate or the terms of trade that makes home goods relatively less expensive than goods produced abroad, there is an instantaneous improvement in the trade balance.

The table shows that when home and foreign goods are less substitutable, either because the Armington elasticity is equal to 0.9 or because there are distribution costs in the model, the contemporaneous correlation between relative prices and net exports falls. The models with a low substitutability between home and foreign goods predict that the contemporaneous correlation between the terms of trade and net exports is about -0.36 . In the model without distribution costs the real exchange rate is perfectly correlated with the terms of trade, and thus the correlation between the real exchange rate and net exports is also -0.36 . In the model with distribution costs the real exchange rate and the terms of trade are no longer perfectly correlated, but the model still predicts a low correlation between the real exchange rate and net exports. ${ }^{11}$

Backus et al. go on to describe the S-curve. The fact that the correlation between the terms of trade at time $t$ and net exports at time $t+n$ looks like a horizontal letter $\mathrm{S}$ as $n$ goes from some negative integer to some positive integer. Most importantly, the S-curve shows the fact that the contemporaneous correlation between net exports and international relative prices is negative, but the correlation between relative prices today and net exports at time $t+n$ is positive for some positive $n$, implying that the immediate impact of an exchange rate depreciation may be a fall in the trade balance, but a depreciation eventually leads to an increase in net exports.

This S-like relationship between relative prices like the real exchange rate or the terms of trade and lags or leads of net exports is presented in figure 5. The figure shows the

\footnotetext{
${ }^{11}$ The fact that the contemporaneous correlation between the terms of trade and the trade balance may be positive or negative is related to the famous Marshall-Lerner condition. When there is a depreciation in the terms of trade, the relative price of imports increases, this means that the quantity demanded of imports will certainly fall and the quantity demanded of a country's exports will certainly rise. Thus when measuring net exports with constant (steady-state) prices, there will certainly be a positive correlation between the terms of trade and the trade balance, as shown in the results for Model-2. However, when the prices that are used to calculated the trade balance also vary, the relative price of imports may increases, and thus the quantity demanded of imports will fall, but if the import demand elasticity is less than 1 then the fall in quantity demanded is not as great as the rise in the price, so the total spending on imports will actually increase, resulting in a negative contemporaneous correlation between the terms of trade and the trade balance.
} 
correlation between relative prices at time $t$ and net exports at time $t+n$ as observed in the data for the United States and the Euro Area, and as predicted by the three versions of the model.

As observed from the S-curves in the data, the correlation between relative prices at time $t$ and net exports at time $t+n$ is increasing as $n$ increases. Thus there is a negative contemporaneous correlation between either the terms of trade or the real exchange rate and the current value of net exports, but this correlation increases for future values of net exports. When the technological elasticity of substitution is equal to 4 and there are no distribution costs, the model cannot replicate this finding. Counterfactually the model finds that the correlation between relative prices at time $t$ and net exports at time $t+n$ falls as $n$ increases.

However, when the short-run substitutability of home and foreign goods is low, either because the Armington elasticity is low or because frictions in the distribution sector hamper substitutability in the short run, the model can replicate the fact that the correlation between relative prices at time $t$ and net exports at time $t+n$ starts at an initially low level and increases as $n$ increases.

\subsubsection{Separate shocks in the production and distribution sectors}

The results presented so far have assumed that both the production and distribution sectors within a country are affected by the same country-specific TFP shock. This was done to ensure that the results from the model without the distribution sector could be easily compared with the results from the model with a distribution sector. However, as mentioned in section 2, it may be more realistic to assume that within each country there are two shocks, a production sector shock, $A_{t}$, that affects the manufacturing sector, and a service sector shock, $A_{t}^{d}$, that affects the distribution sector. We use data from the OECD's STAN database to calculate country and sector specific TFP processes for both the manufacturing sector and the service sector, and the results from the estimation of this $\operatorname{VAR}(1)$ process with these four shocks was presented in section 2.

The results from simulations of this model are presented in table 6 . Now the comparison between the model with no distribution sector and the model with a distribution sector is not as easy. Since the shocks to the production sector are more volatile than shocks to the services sector, it is not as clear-cut to compare a model where all of the economy is engaged in manufacturing to one where half is manufacturing and half is distribution.

That said, in the model with both sector- and country-specific shocks, most of the same features of the model with only country-specific shocks continue to hold. Namely the fact that in the model with a high technological elasticity of substitution, consumption volatility 
will be counterfactually low, the volatility of the terms of trade and the real exchange rate will be too low, cross-country GDP co-movement will be too low, and cross-country consumption correlation will be too high. These key failings of the model were brought on by the fact that home and foreign goods were too highly substitutable, and thus home and foreign agents could too easily smooth consumption following a county-specific shock. The model with both sector- and country-specific TFP shocks can still lead to key improvements in the ability of the model to match the data since frictions in the distribution sector still hamper the substitutability of home and foreign goods in the short run.

\section{Summary and Conclusion}

The international macro literature uses a low elasticity of substitution between home and foreign goods since a low substitutability is needed to explain short business cycle fluctuations, particularly movements in international relative price and the real exchange rate. The international trade literature measures this elasticity using data on the longer term change in trade patterns following a changes in relative prices, for instance after an exogenous tariff reduction.

This paper presents a model that can explain these two apparently contradictory results. The true elasticity of substitution between home and foreign goods is high, like in the trade literature. However in the short run there are frictions in distribution that makes home and foreign goods appear much less substitutable in the short run. The model is parameterized to produce this high long-term elasticity, but simulations of the model show that in the short run it behaves like an international macro model parameterized with a low elasticity of substitution. Specifically, the model is able to replicate the short-run volatility of the real exchange rate and the terms of trade. The model can also replicate the negative co-movement between relative prices and both GDP and net exports.

Thus frictions in distribution are one possible reason for the discrepancy between trade and macro estimates of the elasticity of substitution. Other reasons for this low short run elasticity and high long run elasticity include frictions in price setting, frictions in firm entry and exit, and frictions in inventory management. It is left as an interesting direction for further research to empirically measure the relative weights of these competing explanations in explaining the elasticity puzzle. 


\section{References}

Alessandria, George, Joseph P. Kaboski, and Virgiliu Midrigan. 2010. "Inventories, Lumpy Trade, and Large Devaluations." American Economic Review, 100: 2304-2339.

Anderson, James E., and Eric van Wincoop. 2004. "Trade Costs." Journal of Economic Literature, 42(3): 691-751.

Armington, P.S. 1969. "A theory of demand for products distinguished by place of production." IMF Staff Papers, 16: 159-178.

Backus, David K., Patrick J. Kehoe, and Finn E. Kydland. 1994. "Dynamics of the Trade Balance and the Terms of Trade: The J-Curve?" The American Economic Review, 84: 84-103.

Bahmani-Oskooee, Mohsen, and Marzieh Bolhasani. 2008. "The J-Curve: Evidence from commodity trade between Canada and the U.S." Journal of Economics and Finance, 32: 207-225.

Berger, David, Jon Faust, John H. Rogers, and Kai Steverson. 2012. "Border prices and retail prices." Journal of International Economics, 88(1): 62-73.

Blonigen, Bruce A., Benjamin H. Liebman, and Wesley W. Wilson. 1999. "Explaining Armington: What Determines Substitutability between Home and Foreign Goods?" The Canadian Journal of Economics, 32(1): 1-21.

Boyd, Derick, Guglielmo Maria Caporale, and Ron Smith. 2001. "Real Echange Rate Effects on the Balance of Trade: Cointegration and the Marshall-Lerner Condition." International Journal of Central Banking, 6(3): 187-200.

Burstein, Ariel, Joao C. Neves, and Sergio Rebelo. 2003. "Distribution costs and real exchange rate dynamics during exchange-rate-based stabilizations." Journal of Monetary Economics, 50: 1189-1214.

Burstein, Ariel, Martin Eichenbaum, and Sergio Rebelo. 2005. "Large Devaluations and the Real Exchange Rate." Journal of Political Economy, 113: 742-784.

Burstein, Ariel, Martin Eichenbaum, and Sergio Rebelo. 2007. "Modeling Exchange Rate Passthrough After Large Devaluations." Journal of Monetary Economics, 54(2): 346-368.

Campa, Jose Manuel, and Linda S. Goldberg. 2005. "Exchange Rate Pass Through into Import Prices." Review of Economics and Statistics, 87(4): 679-690.

Clausing, Kimberly A. 2001. "Trade Creation and Trade Diversion in the Canada - United States Free Trade Agreement." The Canadian Journal of Economics, 34(3): 677-696.

Corsetti, Giancarlo, and Luca Dedola. 2005. "A macroeconomic model of international price discrimination." Journal of International Economics, 67: 129-155. 
Corsetti, Giancarlo, Luca Dedola, and Sylvain Luduc. 2008. "International Risk Sharing and the Transmission of Productivity Shocks." Review of Economic Studies, 75(6): 443-473.

Crucini, Mario J., and Anthony Landry. 2012. "Accounting for Real Exchange Rates Using Micro-Data." Federal Reserve Bank of Dallas, Globalization and Monetary Policy Institute Working Paper No. 108.

Crucini, Mario J., and Hakan Yilmazkuday. 2009. "A Model of International Cities: Implications for Real Exchange Rates." Federal Reserve Bank of Dallas, Globalization and Monetary Policy Institute Working Paper No. 38.

Devereux, Michael B., and Charles Engel. 2002. "Exchange rate pass-through, exchange rate volatility, and exchange rate disconnect." Journal of Monetary Economics, 49: $913-940$.

Drozd, Lukasz A., and Jaromir B. Nosal. 2012. "Understanding International Prices: Customers as Capital." American Economic Review, 102: 364-395.

Eaton, Jonathan, and Samuel Kortum. 2002. "Technology, Geography, and Trade." Econometrica, 70: 1741-1779.

Enders, Zeno, Gernot J. Müller, and Almuth Scholl. 2011. "How do fiscal and technology shocks affect real exchange rates? New evidence for the United States." Journal of International Economics, 83: 53-69.

Engel, Charles, and Jian Wang. 2011. "International trade in durable goods: Understanding volatility, cyclicality, and elasticities." Journal of International Economics, 83: $37-52$.

Gallaway, Michael P., Christine A. McDaniel, and Sandra A. Rivera. 2003. "Shortrun and long-run industry-level estimates of U.S. Armington elasticities." North American Journal of Economics and Finance, 14: 49-68.

Goldberg, Linda S., and Jose Manuel Campa. 2010. "The sensitivity of the CPI to exchange rates: Distribution margins, imported inputs, and trade exposure." Review of Economics and Statistics, 92(2): 392-407.

Head, Keith, and John Reis. 2001. "Increasing Returns versus National Product Differentiation as an Explanation for the Pattern of U.S.-Canada Trade." The American Economic Review, 91(4): 858-876.

Heathcote, Jonathan, and Fabrizio Perri. 2002. "Financial autarky and international business cycles." Journal of Monetary Economics, 49: 601-627.

Hillberry, Russell, Michael Anderson, Edward Balistreri, and Alan Fox. 2001. "The determinates of Armington taste parameters in CGE models, or why you love Canadian vegetable oil." U.S. International Trade Commisson, Office of Economics Working Paper. 
Hooper, Peter, Karen Johnson, and Jamie Marquez. 1998. "Trade Elasticities for the G-7 Countries." Board of Governors International Finance Discussion Paper No. 609 .

Hummels, David. 1999. "Toward a Geography of Trade Costs." mimeo.

Junz, Helen B., and Rudolf R. Rhomberg. 1973. "Price Competitiveness in Export Trade Among Industrial Countries." American Economic Reveiw (Papers and Proceedings), 63: 412-418.

Kose, M. Ayhan, and Kei-Mu Yi. 2006. "Can the standard international business cycle model explain the relation between trade and comovement?" The Journal of International Economics, 68: 267-295.

Magee, Stephen P. 1973. "Currency Contracts, Pass-Through, and Devaluation." Brookings Papers on Economic Activity, 1973(1): 303-325.

Obstfeld, Maurice, and Kenneth Rogoff. 2000. "The Six Major Puzzles in International Economics: Is there a Common Cause?" NBER Macroeconomics Annual, 15: 339-390.

Romalis, John. 2007. "NAFTA's and CUSFTA's Effect on International Trade." Review of Economics and Statistics, 89(3): 416-435.

Rose, Andrew K. 1991. "The role of exchange rates in a popular model of international trade: Does the Marshall-Lerner Condition hold?" Journal of International Economics, 30: $301-316$.

Ruhl, Kim J. 2005. "Solving the Elasticity Puzzle in International Economics." mimeo, University of Texas - Austin.

Stockman, Alan C., and Linda L. Tesar. 1995. "Tastes and Technology in a TwoCountry Model of the Business Cycle: Explaining International Comovement." American Economic Review, 85(1): 168-185. 


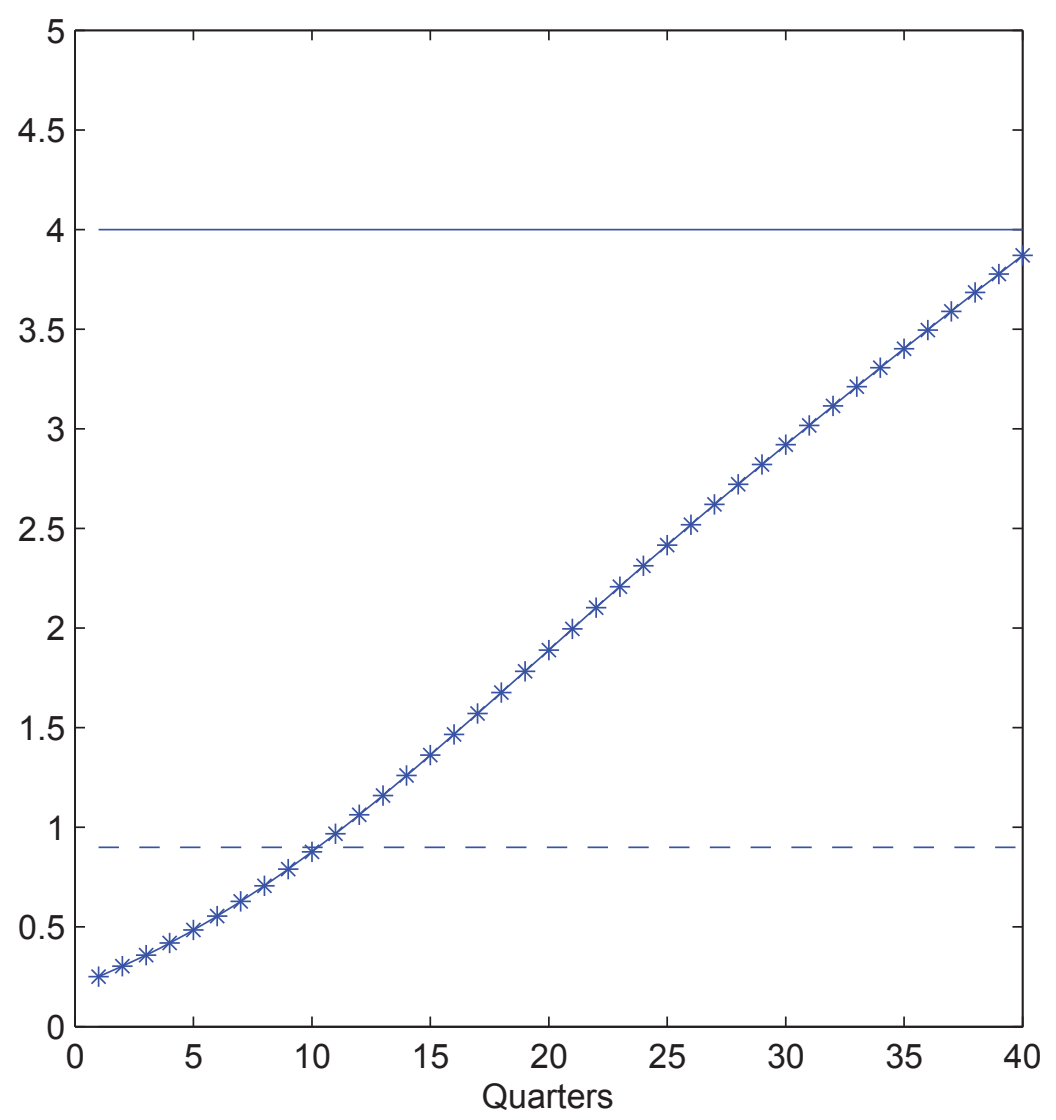

Figure 1: Observed Elasticity of Substitution following a TFP shock. The solid line is where the structural elasticity is equal to 4 and there is no distribution. The dashed line is where the structural elasticity is equal to 0.9 and there is no distribution. The line with stars is where the structural elasticity is equal to 4 and there is distribution.

Table 1: Parameter Values

\begin{tabular}{ccl}
\hline \hline Symbol & Value & Description \\
\hline$\theta$ & 0.66 & weight on leisure in the household's utility function \\
$\sigma$ & 2 & coefficient of relative risk aversion \\
$\alpha$ & 0.36 & capital share in the production of traded goods \\
$\beta$ & 0.99 & discount factor \\
$\omega$ & 0.85 & exogenous preference for home goods \\
$\delta$ & 0.025 & capital depreciation rate \\
$\gamma$ & 0.02 & elasticity of substitution between wholesale goods and distribution services \\
$\alpha_{d}$ & 0.36 & capital's share in distribution costs \\
$\eta$ & 0.40 & elasticity of substitution between capital and labor in distribution \\
$\chi$ & 0.18 & capital adjustment cost parameter for capital used in distribution \\
\hline \hline
\end{tabular}



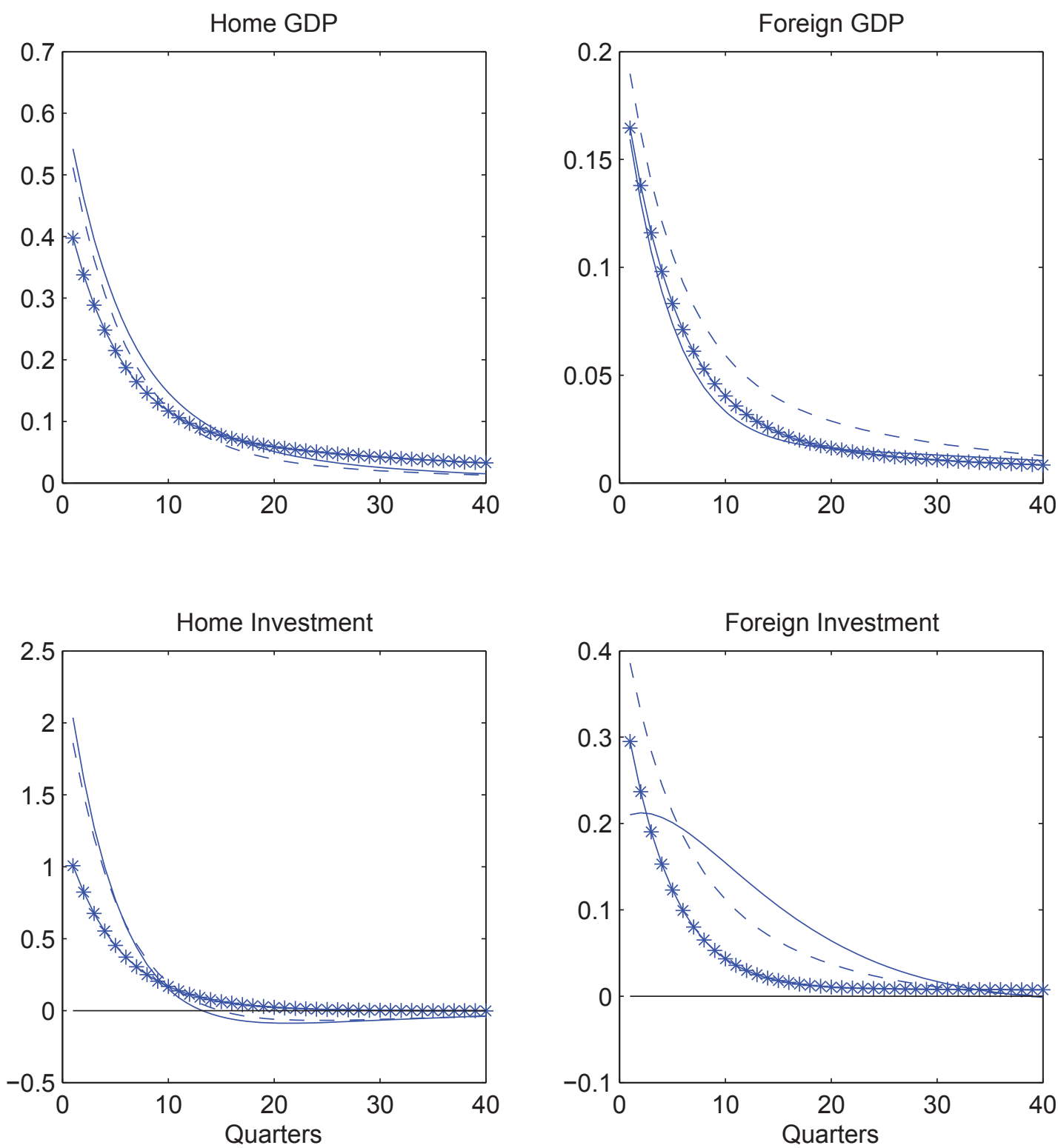

Figure 2: The responses of home and foreign GDP and investment to a positive home TFP shock. The solid line is where the structural elasticity is equal to 4 and there is no distribution. The dashed line is where the structural elasticity is equal to 0.9 and there is no distribution. The line with stars is where the structural elasticity is equal to 4 and there is distribution. 

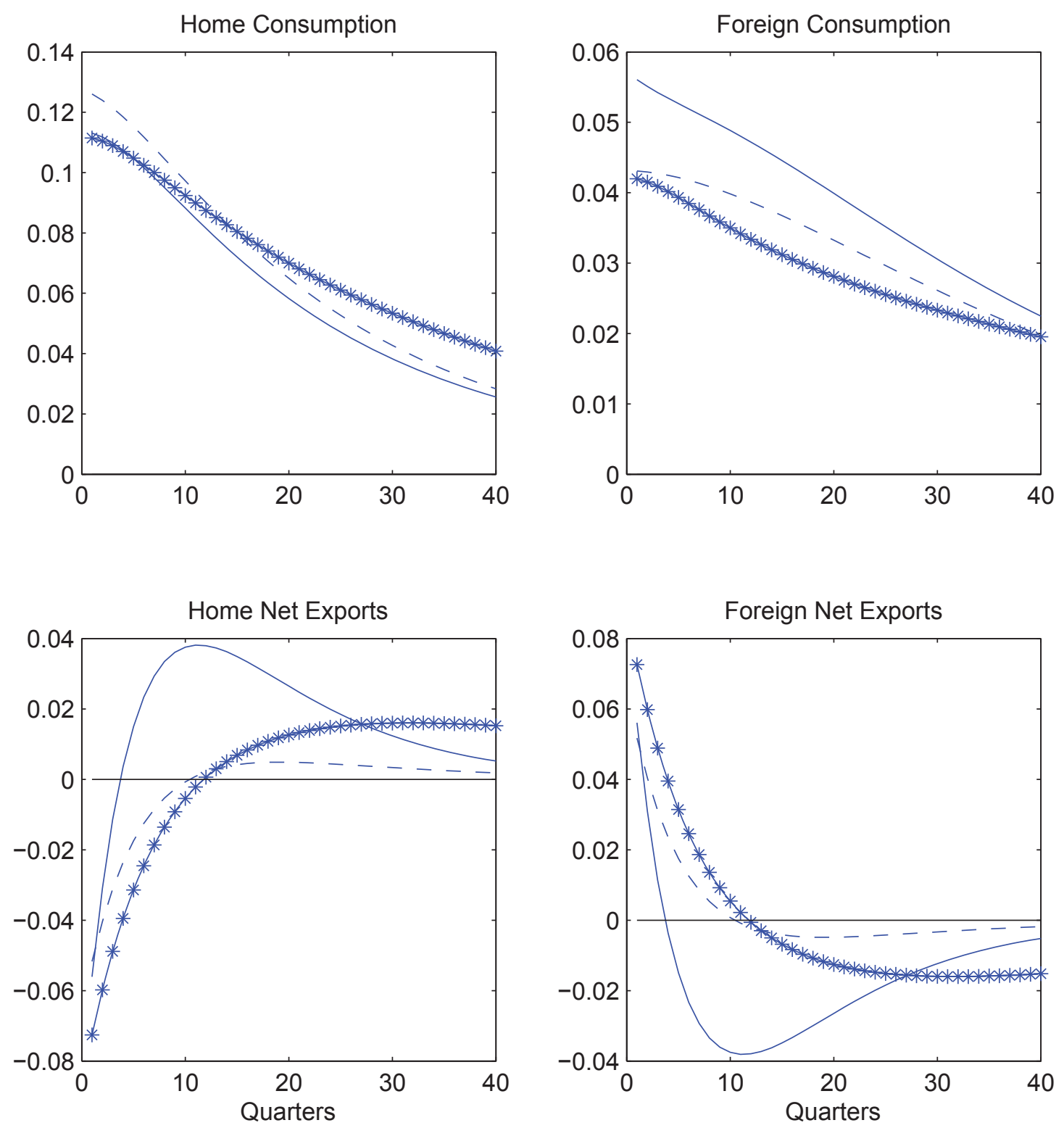

Figure 3: The responses of home and foreign consumption and net exports to a positive home TFP shock. The solid line is where the structural elasticity is equal to 4 and there is no distribution. The dashed line is where the structural elasticity is equal to 0.9 and there is no distribution. The line with stars is where the structural elasticity is equal to 4 and there is distribution. 

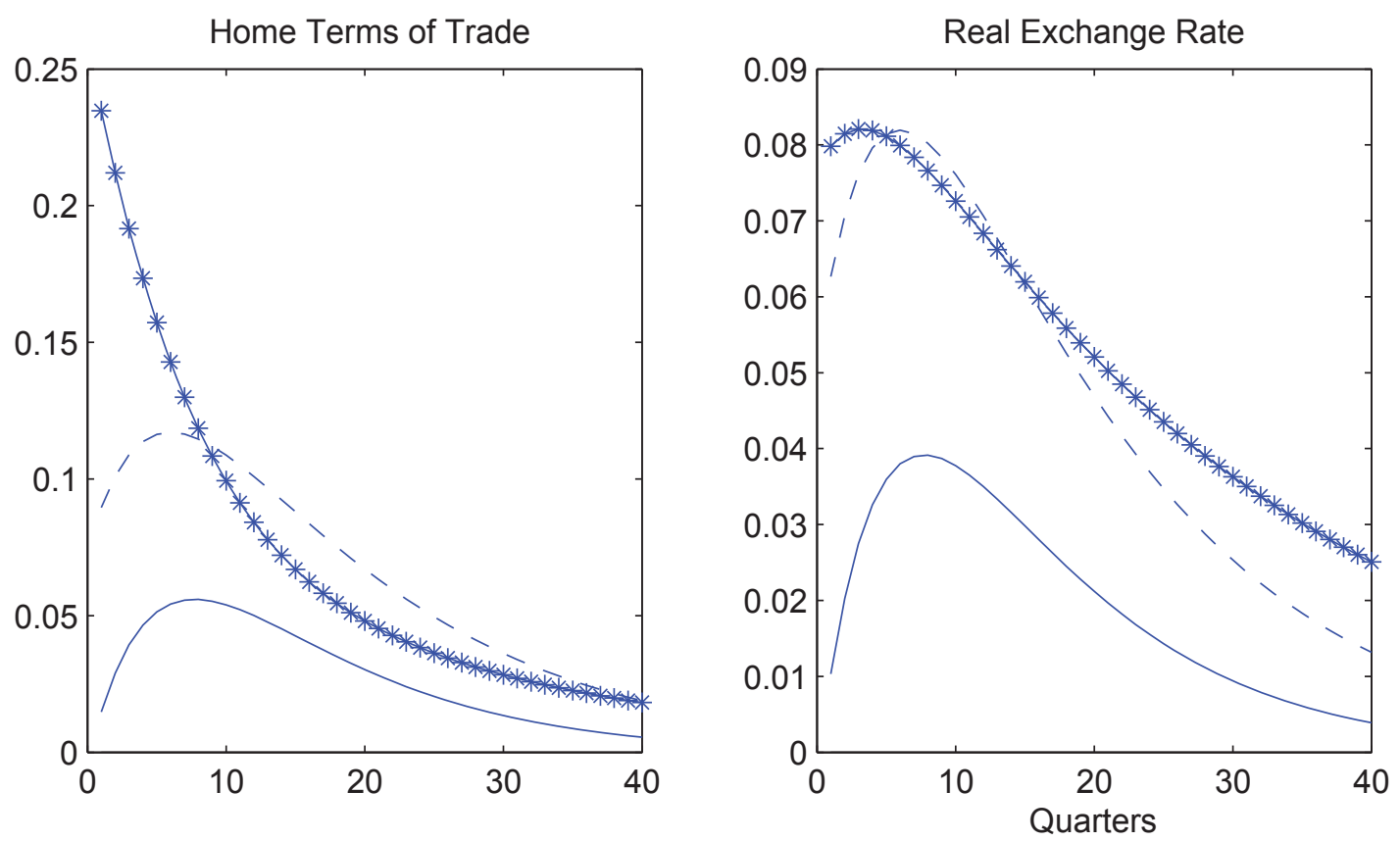

Figure 4: The response of the home country terms of trade and the real exchange rate to a positive home TFP shock. The solid line is where the structural elasticity is equal to 4 and there is no distribution. The dashed line is where the structural elasticity is equal to 0.9 and there is no distribution. The line with stars is where the structural elasticity is equal to 4 and there is distribution. 
Correlation between $\mathrm{NX}(\mathrm{t}+\mathrm{n})$ and TOT $(\mathrm{t})$

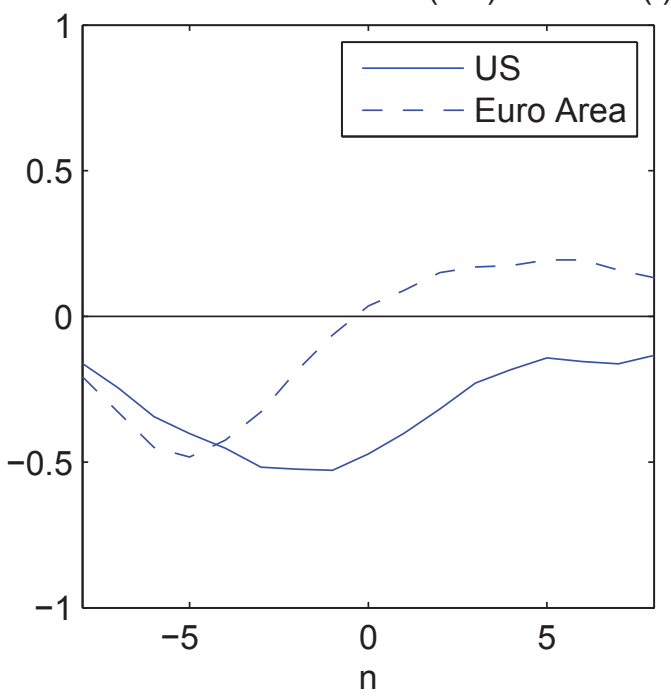

Correlation between $N X(t+n)$ and $\operatorname{RER}(t)$

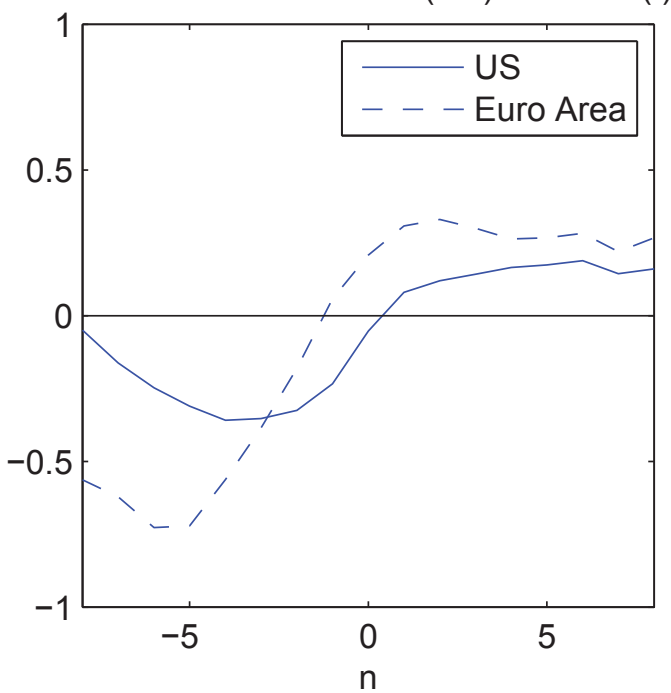

Correlation between $\mathrm{NX}(\mathrm{t}+\mathrm{n})$ and TOT(t)

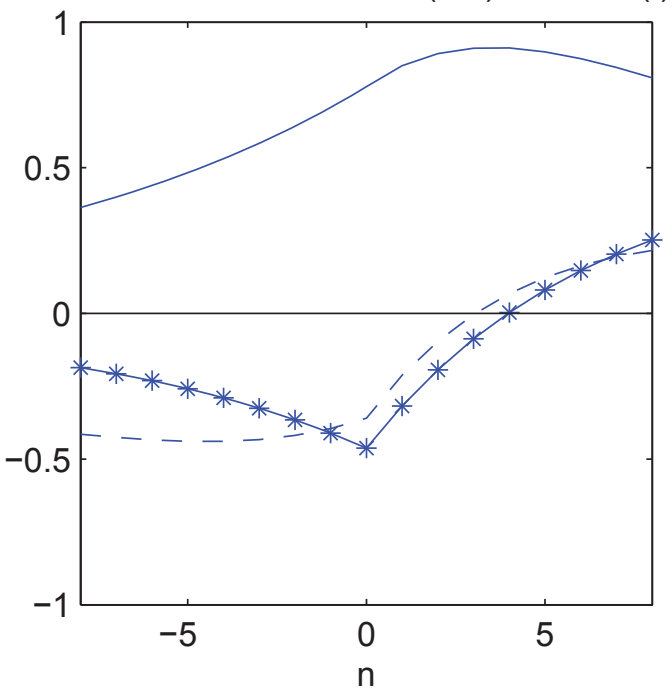

Correlation between $N X(t+n)$ and $\operatorname{RER}(t)$

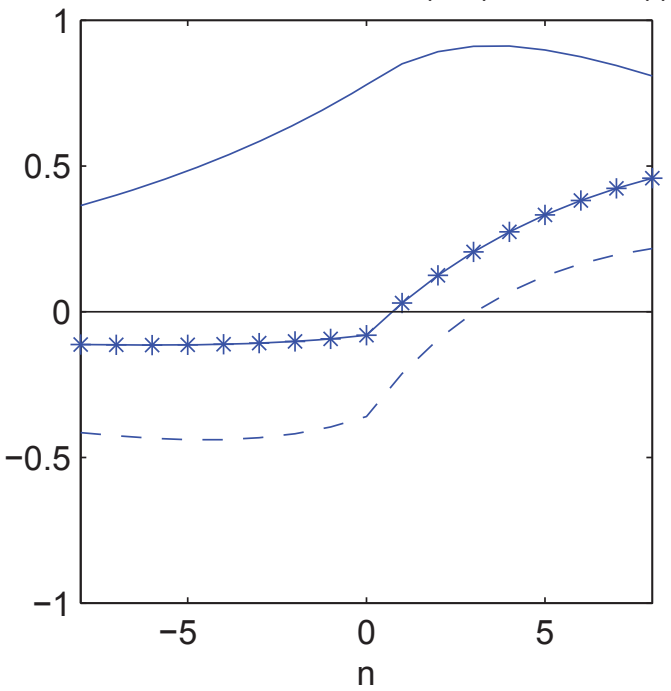

Figure 5: The correlation between relative prices and lagged values of net exports. The solid line is where the structural elasticity is equal to 4 and there is no distribution. The dashed line is where the structural elasticity is equal to 0.9 and there is no distribution. The line with stars is where the structural elasticity is equal to 4 and there is distribution. 


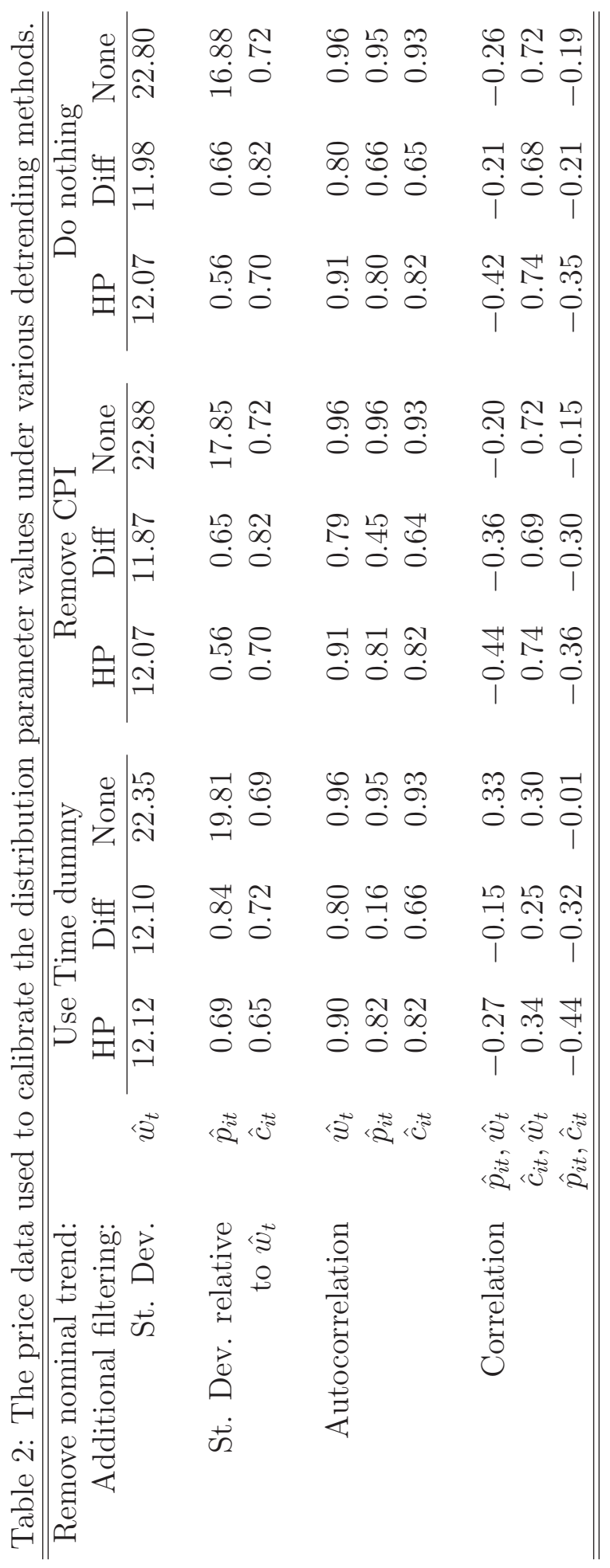




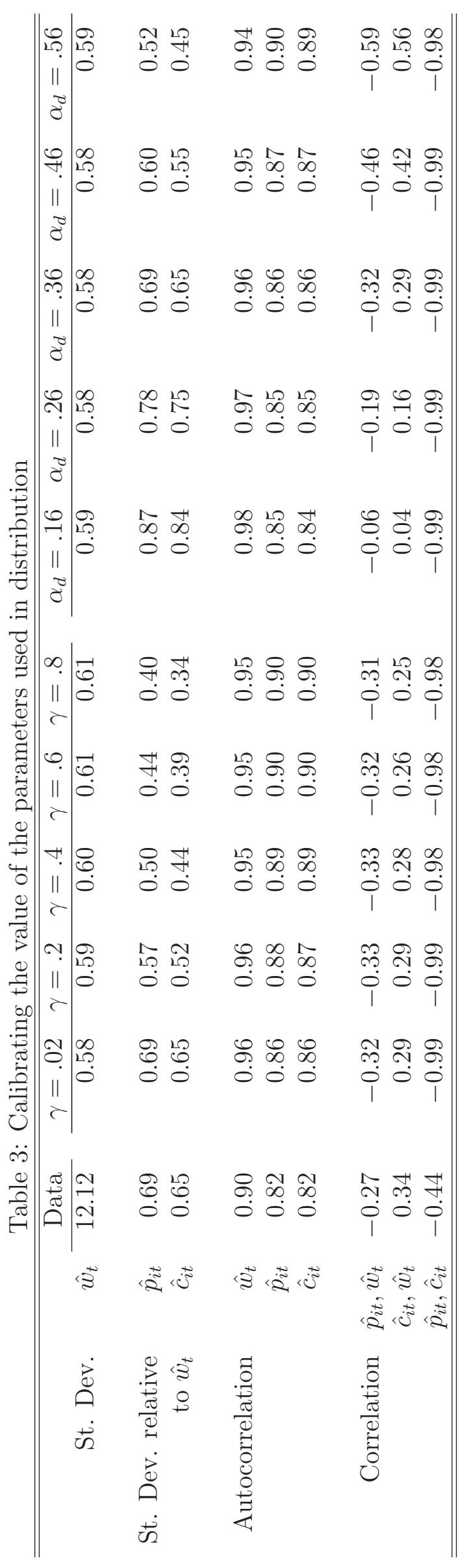




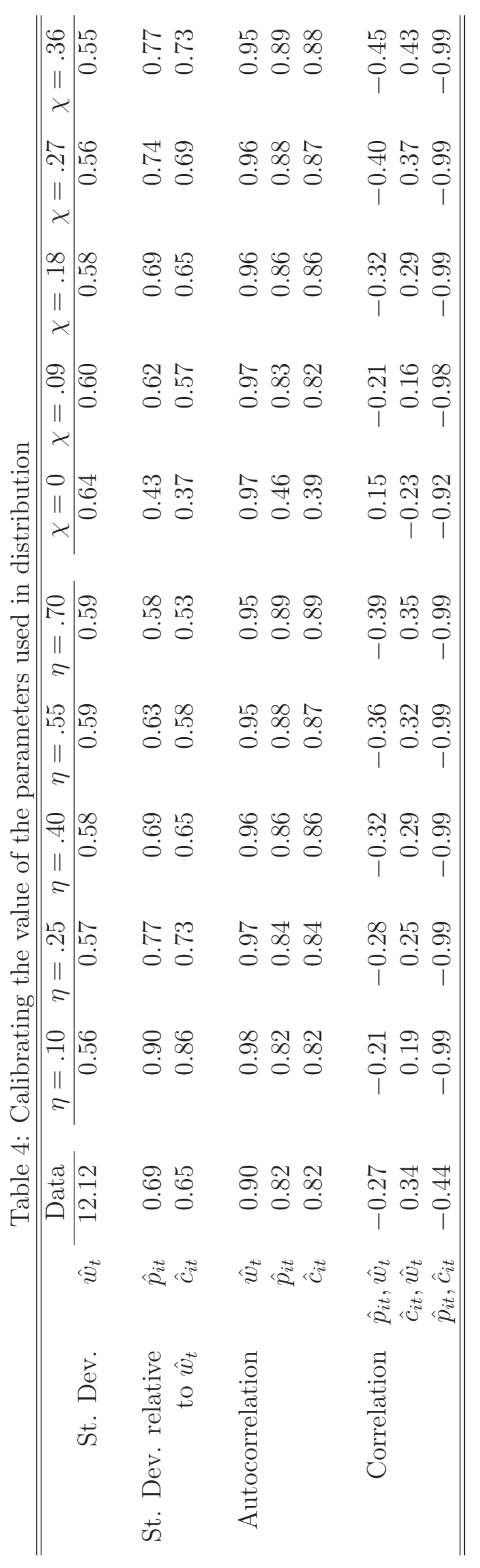




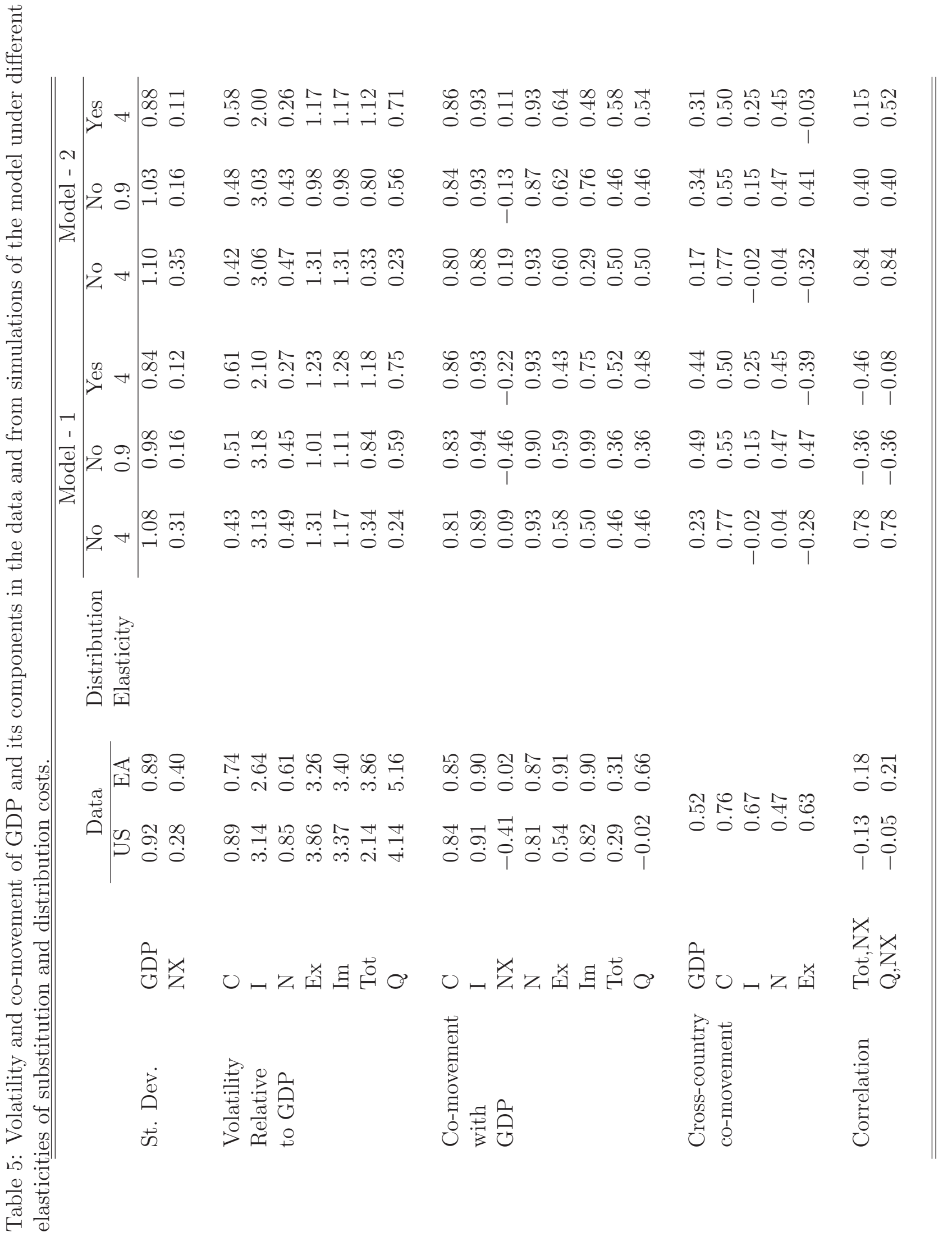




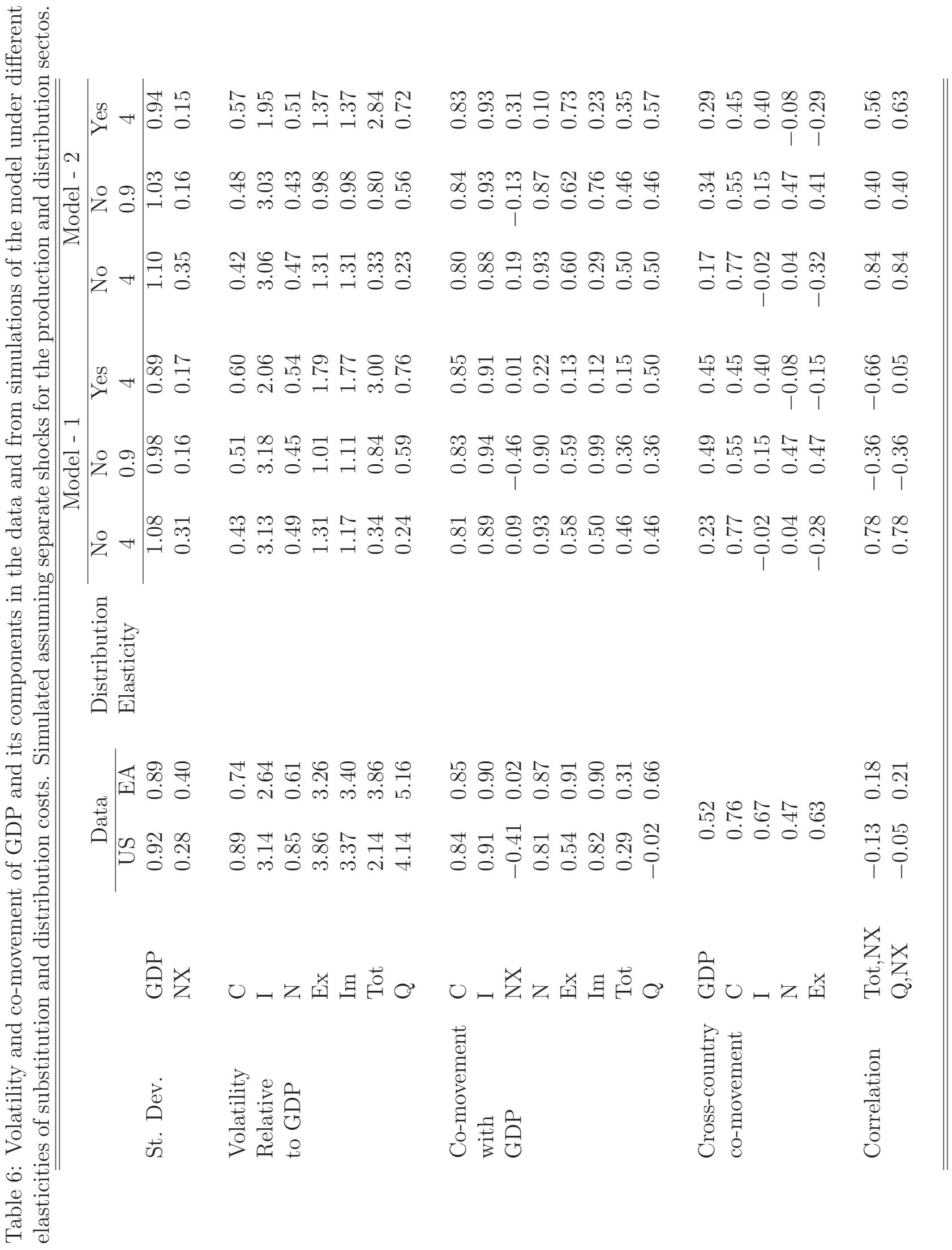

